OPEN ACCESS

Edited by:

Xuguang (Sean) Li, Health Canada, Canada

Reviewed by:

Chengwen Li,

University of North Carolina at Chapel Hill, United States

Chen Ling,

Fudan University, China

*Correspondence:

Guangping Gao

Guangping.Gao@umassmed.edu

${ }^{t}$ These authors have contributed equally to this work

${ }^{\ddagger}$ These authors share senior authorship

Specialty section:

This article was submitted to Vaccines and Molecular Therapeutics, a section of the journal

Frontiers in Immunology

Received: 28 February 2021 Accepted: 23 April 2021

Published: 11 May 2021

Citation:

Zhan W, Muhuri M, Tai PWL and Gao G (2021) Vectored Immunotherapeutics for Infectious

Diseases: Can rAAVs Be The

Game Changers for Fighting

Transmissible Pathogens?

Front. Immunol. 12:673699. doi: 10.3389/fimmu.2021.673699

\section{Vectored Immunotherapeutics for Infectious Diseases: Can rAAVs Be The Game Changers for Fighting Transmissible Pathogens?}

\author{
Wei Zhan ${ }^{1,2 \dagger}$, Manish Muhuri ${ }^{1,2,3 \dagger}$, Phillip W. L. Tai ${ }^{1,2,3 \neq}$ and Guangping Gao ${ }^{1,2,3,4 * \neq}$ \\ ${ }^{1}$ Horae Gene Therapy Center, University of Massachusetts Medical School, Worcester, MA, United States, ${ }^{2}$ VIDE Program, \\ University of Massachusetts Medical School, Worcester, MA, United States, ${ }^{3}$ Department of Microbiology and Physiological \\ Systems, University of Massachusetts Medical School, Worcester, MA, United States, ${ }^{4}$ Li Weibo Institute for Rare Diseases \\ Research, University of Massachusetts Medical School, Worcester, MA, United States
}

Conventional vaccinations and immunotherapies have encountered major roadblocks in preventing infectious diseases like HIV, influenza, and malaria. These challenges are due to the high genomic variation and immunomodulatory mechanisms inherent to these diseases. Passive transfer of broadly neutralizing antibodies may offer partial protection, but these treatments require repeated dosing. Some recombinant viral vectors, such as those based on lentiviruses and adeno-associated viruses (AAVs), can confer long-term transgene expression in the host after a single dose. Particularly, recombinant (r)AAVs have emerged as favorable vectors, given their high in vivo transduction efficiency, proven clinical efficacy, and low immunogenicity profiles. Hence, rAAVs are being explored to deliver recombinant antibodies to confer immunity against infections or to diminish the severity of disease. When used as a vaccination vector for the delivery of antigens, rAAVs enable de novo synthesis of foreign proteins with the conformation and topology that resemble those of natural pathogens. However, technical hurdles like pre-existing immunity to the rAAV capsid and production of anti-drug antibodies can reduce the efficacy of rAAV-vectored immunotherapies. This review summarizes rAAV-based prophylactic and therapeutic strategies developed against infectious diseases that are currently being tested in pre-clinical and clinical studies. Technical challenges and potential solutions will also be discussed.

Keywords: adeno-associated virus, vectors, immunotherapy, gene therapy, vaccines

\section{INTRODUCTION}

Infectious diseases are among the biggest threats to our society. They range from ancient maladies, such as malaria and influenza, to modern illnesses, such as human immunodeficiency virus (HIV)-1 and the coronavirus disease of 2019 (COVID-19) pandemic. Many strategies have been developed to cure patients with these diseases and to eradicate the related pathogens. Most vaccines today function by introducing either an inactivated form of the pathogen, a live-attenuated strain, or a protein subunit of the pathogen into the body. This exposure stimulates antigen-specific adaptive 
immune responses and immunological memory, which can protect the host or mitigate the severity of the infection (1). Vaccines have led to the eradication of small pox and have reduced the global incidence of many other diseases (2). However, certain pathogens have been able to evade vaccineinduced sterilizing immunity via various mechanisms. RNA viruses, such as HIV, hepatitis C virus (HCV), and influenza exhibit high genetic variation among diverse strains across different geographical locations. Viral polymorphism can persist even within the same infected individual, thus limiting the utility of vaccines that are based on a single strain $(3,4)$. In addition, retroviruses have rapidly mutating genomes that permit their escape from adaptive immunity (5). Many pathogens actively suppress inflammation and immunological memory by infecting immune cells and inducing $\mathrm{T}$ cell exhaustion, further preventing the formation of sterilizing immunity $(5,6)$. Broadly neutralizing antibodies (bNAbs) can offer protection against multiple strains. Alternatively, blocking the essential primary host cell receptor with monoclonal antibodies (mAbs) can limit infection by multiple strains. For example, ibalizumab, a CD4-targeting $m A b$, has received United States Food and Drug Administration (FDA) approval for use in multidrug-resistant HIV-1 infections (7). In addition, many $\mathrm{mAbs}$ are under development for the targeted treatment of Ebola, Zika, and COVID-19, among others (8). However, these drugs typically require repeated dosing through intravenous injections and have high production costs (9). Therefore, their practical value is limited, especially in underdeveloped areas of the world. Moreover, the processes involved in generating inactivated virus might damage the native conformation of the antigen; while in the case of subunit vaccines, the antigen is often produced using cell lines of non-human origin, which may have distinctive post-translational modification patterns not native to the virus $(10,11)$. Collectively, these issues may create antigens with altered conformations, resulting in antibodies that are produced which do not neutralize the real pathogen. These low-potency antibodies also run the risk of enhancing virus entry by assisting viral attachment to the host cell in a phenomenon termed antibody-dependent enhancement (ADE). One of the biggest concerns with the recent COVID-19 pandemic, which is caused by the severe acute respiratory syndrome coronavirus 2 (SARS-CoV-2), is the possibility of vaccine-mediated ADE effect, since similar outcomes have been observed with other coronavirus infections (12). To counter this, Pfizer/BioNTech and Moderna have each developed a vectored strategy, in which mRNA encoding the coronavirus spike (S) protein packaged in lipid nanoparticles (LNPs) is delivered to the body to mediate de novo synthesis of the S protein, so that the conformation and topology of the antigen best resembles the native protein that is decorated on SARS-CoV-2 (13, 14). This strategy achieved astounding efficacies of $94 \%$ or more in phase III trials (ClinicalTrials.gov Identifier NCT04368728 and NCT04470427).

The ability of viral gene transfer systems to deliver functional genes in the host greatly expands the number of strategies that can be used to fight infectious diseases. One such strategy is to use a recombinant virus as a vector to deliver genes encoding therapeutic molecules, such as neutralizing antibodies (NAbs), bNAbs, therapeutic mAbs, and immunoglobulin (Ig)-related derivatives, for direct expression from the host's tissues, thus negating the necessity of repeated dosing. Viral vectors may also be used to deliver antigen-encoding genes for vaccination against the antigen. Vectors based on adeno-associated viruses (AAVs) are by far the most popular choice for in vivo gene delivery, as a result of their relatively low immunogenicity, high safety profile, broad tropism to a range of tissue types, and their propensity to maintain long-term gene expression. This review will cover recombinant (r)AAV-based immunotherapeutic strategies used to combat infectious diseases. An overview of other viral vectors used in vaccines and immunotherapeutics will be introduced, followed by a general biology of AAV. Subsequently, we will discuss technical challenges and potential solutions to rAAVvector approaches. Finally, the numerous prophylactic and therapeutic strategies that have been developed over the years for various infectious diseases will be highlighted.

\section{Overview of Viral Vector Gene Delivery Systems}

Viral gene delivery systems take advantage of natural viruses' inherent ability to evade host defense mechanisms and to transfer genetic cargos inside the cell. In general, viral systems offer better delivery efficiencies to the nucleus than non-viral systems, such as LNPs, naked DNAs, or various polymeric complexes. At the same time, viral vectors are more immunogenic, which can be desirable or unwanted, depending on the specific application (15). Many viral vector platforms based on adenovirus, lentivirus, AAV, Sendai virus, poxvirus, measles virus, baculovirus, and herpes simplex virus vectors, to name a few, have been explored for gene delivery, with the first three being the current most common (16-20).

Adenoviral vectors (AdVs) have a packaging capacity of up to $34 \mathrm{~kb}$, mediate rapid gene expression, can potently activate innate immune responses, and can induce strong Th1-polarized adaptive immunity against transgene products (21-23). These features make AdVs attractive for vaccination against infectious disease outbreaks. Human adenovirus type 5 (Ad5), type 26 (Ad26), and chimpanzee adenovirus ChAdOX1 have been explored as delivery vectors for the coronavirus $\mathrm{S}$ gene, with the latter achieving 70\% efficacy in a phase III trial (NCT04400838) (24-26). The SARS-CoV2-Ad26 vaccine developed by Johnson \& Johnson, recently received from the FDA an emergency use authorization approval. At the same time, the strong immunogenicity of AdVs, as well as pre-existing immunity against Ad5 among various human populations, can negatively affect transduction efficacy, transgene longevity, and can cause untoward side effects (27). Ad5 vectors encoding mAbs or Ig derivatives against respiratory syncytial virus (RSV) and H5N1 influenza A virus hemagglutinin (HA) demonstrated short-term (4 to 14 days) protection in mice against these respective viruses $(28,29)$. Ad5 delivery of mAbs against anthrax (Bacillus anthracis) showed initial protection from a bacterial toxin challenge, but was lost within six months (30). Recombinant AdVs that express $\mathrm{HIV}-1$ proteins to elicit vaccination of patients 
against HIV-1 infection have been explored, but lacked efficacy in human trials (31-33).

Lentiviral vectors (LVs) utilize the capacity of lentiviruses, most notably HIV-1, to mediate semi-random integration of DNA into the host cell genome to enable long-term transgene expression $(34,35)$. By deleting the genes that are non-essential to vector production or expressing them in trans, LVs can accommodate up to $10 \mathrm{~kb}$ of sequence and have the potential to transduce both mitotic and postmitotic cells $(23,36)$. LVs are commonly used for ex vivo gene delivery, most prominently in hematopoietic stem cells (HSCs) and T cells, and are an essential production component in the two FDA-approved chimeric antigen receptor (CAR)-T cell therapies (37). Current LVs have limited tropism profiles, which is a bottleneck for in vivo gene delivery in preclinical trials $(23,38-41)$. However, pseudotyping with envelope proteins from other viruses can enhance tissue targeting (42). Other issues for LVs are their potential for genotoxicity and immunogenicity. Integrasedefective LVs may reduce genotoxicity and have been used for episomal delivery with varying degrees of success $(43,44)$. Alternatively, packaging LVs with nucleases as protein cargos inside the virion might reduce long-term genotoxicity concerns $(45,46)$.

\section{Characteristics of AAV and Their Recombinant Vector Counterparts}

Wild-type (wt)AAVs are non-enveloped dependoparvoviruses with a relatively simple architecture (Figure 1). Each virion consists of a total of 60 monomers of the capsid proteins (cap), VP1, VP2, and VP3. These proteins respectively assemble at a roughly $1: 1: 10$ ratio into an icosahedral virion that is approximately $25 \mathrm{~nm}$ in diameter and 3.9 MDa in size. Multiple AAV serotypes, that differ in cap proteins, are being tested as gene therapy vectors in numerous clinical trials; with each serotype characterized by their unique tissue tropism profiles. Thirteen different AAV serotypes (AAV1-13) and more than 100 natural variants have been reported so far, and more are being discovered. AAV1, AAV2, and AAV9 have been approved for clinical use by the FDA or European Medicines Agency (EMA), and more are being tested in phase I and phase II trials $(23,47,48)$. Additionally, the AAV capsid can accommodate various modifications, such as amino acid substitutions, post-translational processing, and
A

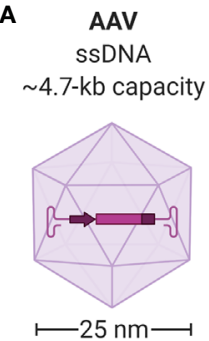

B

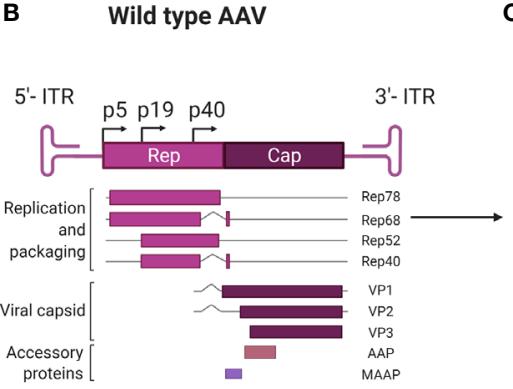

C Recombinant AAV
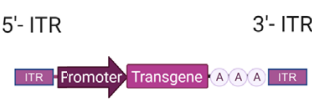

$+$

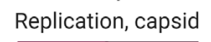

Helper
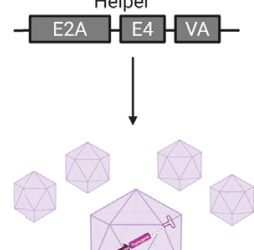

D
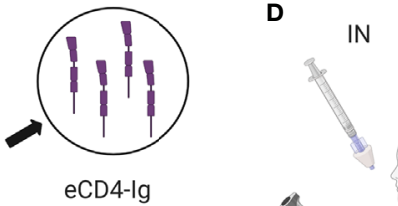

IC

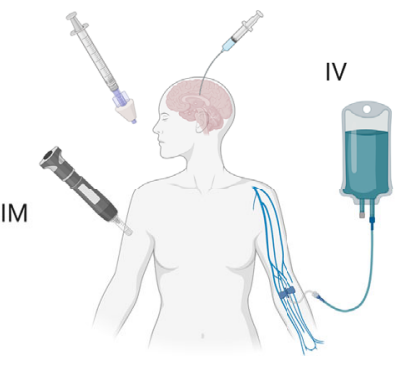

$\infty$

Recombinant

AAV virions

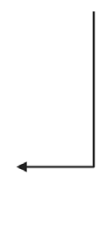

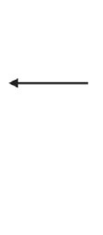

Antigen

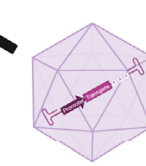

eCD4-Ig

Ig derivatives

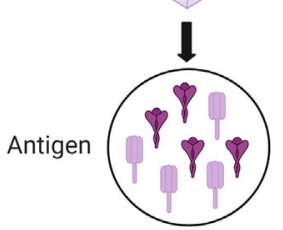

FIGURE 1 | Overview of AAV vectors harnessed for vectored immunoprophylaxis and therapeutics. (A) AAVs are small ( 25 nm), non-enveloped viruses and have a 4.7-kb, single-stranded, linear DNA (ssDNA) genome encoding four open reading frames. (B) rep encodes the four genes required for genome replication (Rep78, Rep68, Rep52, and Rep40) and cap encodes the structural proteins of the viral capsid (VP1, VP2 and VP3). A third gene, which encodes assembly activating protein (AAP), is embedded within the cap coding sequence in a different reading frame and has been shown to promote virion assembly. The fourth ORF encodes for the recently discovered membrane associated accessory protein (MAAP). The role of MAAP is yet to be clearly defined. (C) Providing rep and cap in trans enables a transgene of interest to be packaged inside the capsid to generate a replication-incompetent vector (recombinant AAV; rAAV). (D) rAAVs may be delivered via intramuscnular (IM), intranasal (IN), intracerebral (IC), and intravenous (IV) routes. (E) rAAVs expressing mAbs, eCD4-lg and pathogenic antigens can be administered via different routes for therapeutics and immunization against infectious diseases. Created with BioRender.com. 
chemical alterations (38). This versatility enables the selection of AAV vectors that are better at avoiding pre-existing immunity, targeting the desired tissue, or modulating immune responses.

The encapsidated AAV genome consists of a 4.7-kb linear, single-stranded (ss)DNA that harbors four known open reading frames: rep, which encodes for the replication proteins; cap, which encodes VP1-3; assembly-activating protein $(A A P)$, which promotes capsid assembly within the host cell nucleus; and membrane-associated accessory protein $(M A A P)$, whose function is not completely known. The genome is flanked by two T-shaped hairpin structures called inverted terminal repeats (ITRs) $(23,48,49)$.

To create rAAV vectors, the genome of wtAAV, save for the ITRs, can be deleted to free up to $4.6 \mathrm{~kb}$ of space for transgene cassette packaging (Figure 1). Following rAAV transduction, the linear ssDNA genome is converted into circular double-stranded (ds)DNA episomes that reside within the nucleus and are shielded from exonucleases. These episomes are thus highly stable, non-genotoxic, and can be continuously transcribed to enable long-term transgene expression (50-52). For instance, the transgene for the blood coagulation factor IX (F.IX) in one clinical trial patient persisted for more than ten years (53). Alternatively, integration of the rAAV-delivered DNA into the host genome may occur at low frequencies (54, 55). Selfcomplementary (sc)AAV vectors, in which the sense and the anti-sense sequences of the transgene are packaged inside the vector, can bypass the ssDNA to dsDNA conversion step (23, 48). This allows faster transgene transcription and higher transduction efficiency, but reduces the cargo size by half.

On their own, wtAAVs are non-replicating and require helper viruses, such as adenovirus or herpesvirus to complete their life cycle, while rAAV vectors as a single formulation can deliver transgenes to cells both in vitro and in vivo. In vitro, rAAV is able to transduce many types of primary human and animal cells, as well as cell lines. This ability is highly dependent on the AAV serotype and the cell type (56). Multiple studies have used rAAV vectors to modify cells ex vivo, whereby the cells are isolated from a patient, modified by vectors, and then transplanted back to the host $(57,58)$. Natural AAV infections are typically asymptomatic in humans. Nonetheless, several recent reports and clinical trials have demonstrated that immune responses were mounted by the host against rAAV vectors and their transgene products. These findings have been covered by multiple comprehensive reviews describing the known immune pathways triggered by rAAV administration (59-61). But overall, rAAV vectors are non-pathogenic with relatively low immunogenicity profiles, making them attractive for in vivo transgene delivery. In the context of infectious diseases, rAAV vectors have been used to deliver mAbs and Ig derivatives to achieve prophylactic and therapeutic benefits. Additionally, rAAV vectors have been used as antigenic gene delivery vehicles; because unlike adenoviruses, rAAVs can confer strong immune response against the transgene with minimal response towards the delivery vehicle $(62,63)$. In certain cases, rAAVs can induce greater and more sustained antibody responses than other vaccination approaches (62). The different modalities for immunotherapeutics, including non-vectored, vectored, and rAAV-vectored approaches, are summarized in Figure 2.

\section{Using rAAVs for De Novo Antigen Expression and Induction of Active Immunity}

Unlike inactivated, live-attenuated, or subunit vaccines, all of which deliver foreign immunogens in the form of proteinaceous antigens directly to the host, nucleic acids-based vaccines deliver the gene that encodes the antigen for de novo synthesis in the host's cells $(1,2)$. This strategy simulates the antigen expression process during a natural infection, thus preserving the conformation, topology, multimerization, and glycosylation features of the natural antigen. Conceptually, this should allow the generation of high-quality antibodies that are highly specific to the functional target antigen, and reduce the risk of cross-reactivity and $\mathrm{ADE}$ (12). If mutations were to arise during an ongoing infection, the genetic sequence carried by the vaccine vector can be quickly modified without dramatic changes in the manufacturing process; while in the case of inactivated vaccines, the production of variants usually requires many more steps of re-optimization. Despite these advantages, nucleic acids-based vaccines do come with an important concern: the delivery of exogenous antigens into the host may lead to inflammation-mediated toxicity against the transduced tissue. In such cases, vectors can be specifically engineered to target only select tissues without affecting others, via cell type-specific expression cassette designs.

Nucleic acids-based vaccine strategies can be broadly categorized into DNA- and RNA-based vaccines. DNA-based vaccines tend to allow longer and more stable antigen expression, but present risks for host genome integration and genotoxicity. In contrast, RNA-based vaccines do not interfere with the genome, but are less stable and may require additional support for optimal function, such as cold-chain storage and booster shots $(2,13,14)$. rAAVs are DNA vectors that exhibit relatively low genotoxicity and high stability (64). The first use of an rAAV as a vaccine carrier was in an intramuscular delivery of the herpes simplex virus (HSV)-2 glycoprotein $\mathrm{B}(\mathrm{gB})$ or glycoprotein $\mathrm{D}(\mathrm{gD})$ antigen to induce active immunity against HSV-2 in mice (65). This treatment resulted in antigen-specific cytotoxic $\mathrm{T}$ lymphocyte (CTL) responses and induction of humoral immunity that was more effective than treatments with protein subunits of the antigen or antigenencoding plasmid DNA. This proof-of-concept study opened a new avenue for rAAV-based genetic vaccines.

\section{Using rAAVs for Enhancing Humoral Immunity}

Strategies for rAAV vectors to deliver therapeutic antibodies or Igderivatives to enhance humoral immunity are under development. Humoral immunity is mediated by antibodies, which are highly functional molecules that play critical roles in the host defense against pathogens $(66,67)$. Each antibody monomer is a Y-shaped molecule with two antigen-binding fragment (Fab) arms and one Fc tail that is capable of host cell ligation via $\mathrm{Fc}$ receptors $(\mathrm{FcR})$. Upon first encounter with the pathogen, antibodies of the IgM isotype are released from activated B cells. This isotype has a 


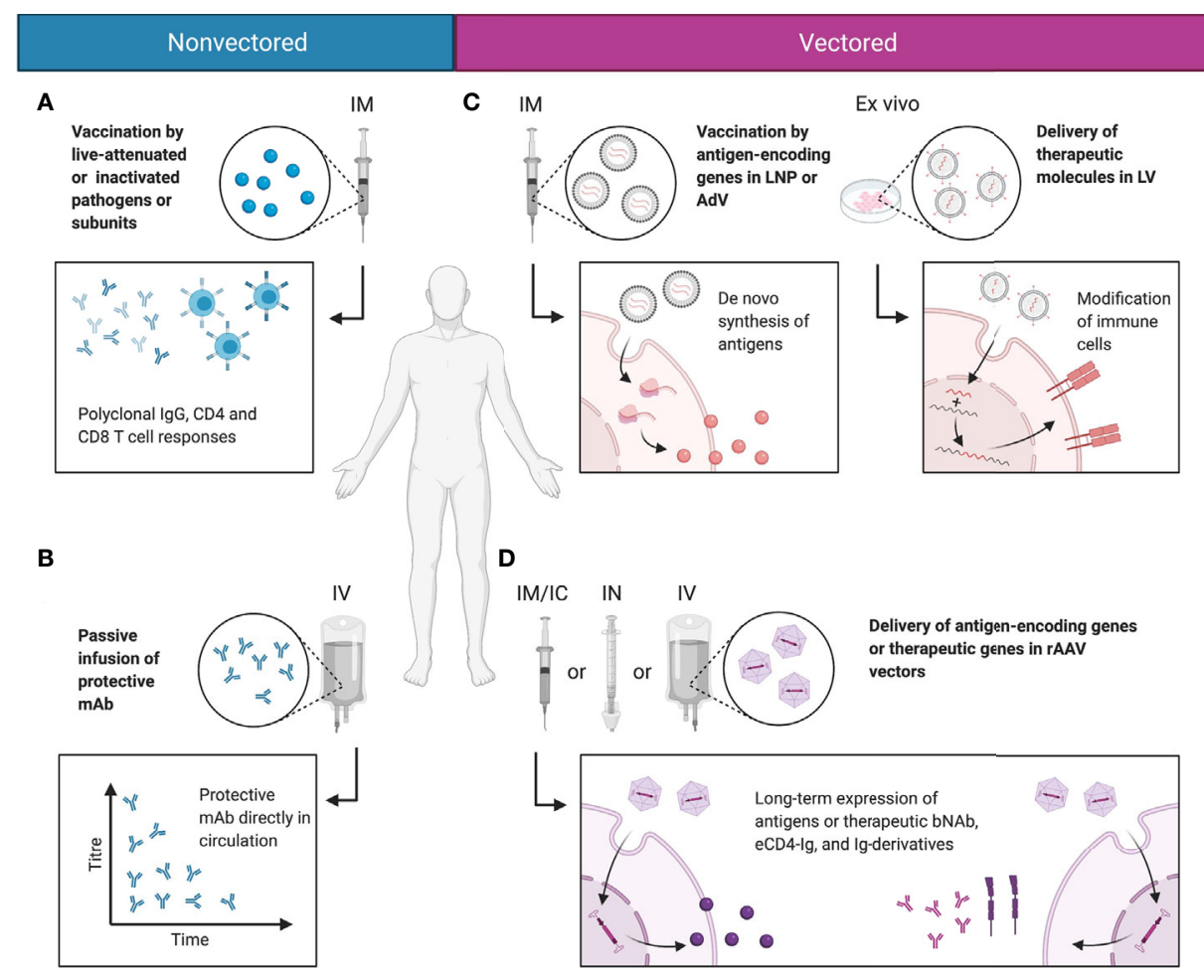

FIGURE 2 | Comparisons between non-vectored and vectored immunotherapeutic strategies. (A) Most vaccines today function by delivering antigen in the form of live-attenuated or inactivated pathogens or antigen subunits. This induces polyclonal humoral and cellular responses and immunological memory that protect the host from infections. (B) In rapidly mutating pathogens that evade normal vaccine-induced immunity, protective mAbs may be directly delivered to the blood stream via passive infusion to mediate protective function. (C) Alternatively, genetic material may be delivered in LNPs or viral vectors, such as AdV or LV. This mediates de novo synthesis of the antigen in the natural conformation, or allows the modification of immune cells into stronger effector cells. (D) rAAV vectors deliver the genetic material of the encoded antigen or therapeutic molecule putatively to the nucleus, as persistent episomes for gene expression. This enables long-term expression of the antigen or therapeutic molecule in a native conformation and topology, and reduces the need for drug redosing. Created with BioRender.com.

pentameric structure with a total of ten antigen-binding sites that enables high-avidity, low-affinity binding for quick antigen recognition. Activated $\mathrm{B}$ cells then undergo clonal selection and somatic hypermutation to release antibodies of the IgG isotype, which exhibit high-affinity binding of the invading pathogen. The vast majority of prophylactic and therapeutic mAbs developed to date are IgG antibodies (68).

Under ideal situations, the above processes eventually lead to the production of potent IgGs that are capable of neutralizing the pathogen, targeting it for processing and degradation in antigenpresenting cells (APCs). In addition, certain IgG-producing B cells gain a memory phenotype that confers long-term immunity against reinfections (69). However, this ideal situation is not always achievable in certain infections, as a result of various pathogen-specific issues. In some cases, the pathogen has highly variable antigens, which may be due to their rapid mutation rates or large geographical distributions. For these pathogens, such as HIV-1 and influenza, rAAV vectors can be used to mediate longterm expression of therapeutic recombinant bNAbs $(70,71)$. If successful, these approaches would be especially useful for the protection of elderly and immunocompromised people, whose humoral response is impaired.

\section{PRACTICAL CONSIDERATIONS IN DEVELOPING rAAV-VECTORED IMMUNOTHERAPIES}

rAAV vectors are showing great potential for treating patients with genetic diseases, but if rAAVs are to be deployed for the prevention and treatment of infectious diseases, additional factors need to be considered. Namely, animal studies of current rAAVbased immunotherapeutics have also revealed many issues to be solved before deployment in a clinical setting. Some of these issues, such as rAAV packaging size and pre-existing immunity against the rAAV capsid, are limitations that are inherent with rAAVbased gene delivery systems. Other challenges, such as anti-drug antibodies (ADAs), mAb-mediated toxicity, and issues related to long-term antigen expression in non-target tissues, are unique challenges for rAAV-based immunotherapy platforms. Advancements in AAV vectorology and virology research may help overcome some of these concerns.

\section{rAAV Cargo Size}

Using rAAVs to deliver mAbs is a well-explored rAAV-mediated immunotherapy modality. A full-length $\mathrm{mAb}$, which is 
composed of two identical heavy chains ( 450 aa) and two identical light chains ( 220 aa), requires a $\sim 2-\mathrm{kb}$ packaging space minimum for the cDNA alone. Together with promoter sequences, cis-regulatory elements, and other components, each rAAV vector may only accommodate one full-length mAb (72). This may present a therapeutic challenge, since pathogens like HIV-1 optimally require co-delivery of several bNAbs to better suppress escape mutants $(73,74)$. Regarding rAAV-vectored bNAb delivery, co-injection of three rAAV1 vectors, each encoding a distinctive bNAb, was explored in rhesus macaques (71). Sustained expression of two out of three bNAbs was observed in one rhesus macaque with low ADA.

If scAAV vectors are used for faster $\mathrm{mAb}$ generation, the heavy and light chains of the mAb would need to be packaged into more than one rAAV vector (75). When dealing with cargoes that exceed the packaging capacity of AAV vectors, several strategies can be used $(76,77): 1)$ once inside the cell nucleus, the vector DNAs may reconstitute into the full-length transgene through homologous recombination; 2) the mRNAs from each cargo can be engineered to undergo trans-splicing into a single mRNA transcript for full-length transgene expression; and 3) the polypeptide products of the cargos can be joined into fulllength proteins via intein-mediated trans-splicing. The DNA and mRNA recombination-based methods would require cotransduction of the same cell by two rAAV vectors, which can be efficiency-limiting. Intein-mediated protein trans-splicing can presumably work extracellularly and eliminates the need for cotransduction of the same cell (78). Given that mAbs are secreted, intein-based methods may be more appropriate in the context of rAAV-mediated immunotherapy. Alternatively, smaller Igderivatives, such as bivalent single-chain variable fragments (scFvs), immunoadhesins, or chimeric Ig-like molecules that combine the functional domain with the Fc domain, may suffice as therapeutic surrogates for full-length mAbs (79-82).

\section{ADAs}

Passively administered $\mathrm{mAbs}$ and AAV-delivered mAbs are subject to reduced potencies by ADAs, which come in the form of host antibodies that target exogenous mAbs (83-85). The clinical sequela of ADAs developed against infused mAbs tend be mild. Patients with $\mathrm{ADAs}$ may require higher therapeutic $\mathrm{mAb}$ doses. But in extremely rare cases, ADA may be associated with anaphylactic shock $(85,86)$. For AAV-vectored mAb delivery, $\mathrm{ADAs}$ are almost universally detected in preclinical studies that looked for them and are considered the main reason for declining therapeutic mAb titers over time. ADAs can appear as early as two weeks post-AAV transduction and animals with higher levels of ADAs usually present with lower levels of therapeutic mAbs in the blood stream $(71,87,88)$. On the plus side, no severe adverse events have been documented in preclinical and clinical studies when ADAs against rAAV-delivered mAbs were detected (89).

Developing a generic solution to ADAs is challenging because ADA development is still an enigmatic process. Therapeutic mAbs might be prone to inducing ADAs, as they are large proteinaceous foreign antigens. However, not all hosts receiving the same mAbs develop ADA. This phenomenon is true for passively administered $\mathrm{mAbs}$ and $\mathrm{rAAV}$-delivered $\mathrm{mAbs}$ in humans
(NCT01937455) $(71,87,89,90)$. Also, new mAbs are constantly generated via $\mathrm{V}(\mathrm{D}) \mathrm{J}$ recombination and somatic hypermutation during natural immune responses, but no ADAs against endogenous $\mathrm{mAbs}$ have been documented. One important difference among endogenous mAbs and rAAV-delivered mAbs is that their site of production is vastly different. The former is endogenously produced in B cells, while the latter is exogenously expressed in other tissues, most commonly the muscle (Table 1). Differences in post-translational processing, like the glycosylation of $\mathrm{mAbs}$ with non-native cell types might introduce novel epitopes that can potentiate the development of ADAs (125). One study demonstrated that rAAV8-delivered mAbs presented different glycosylation patterns than mAbs derived from infection of cells in vitro (88). If these findings hold true in clinical settings, then one possibility of reducing ADAs is to use $\mathrm{B}$ cell-targeting $\mathrm{rAAV}$ vectors, such as those based on AAV6, for preferential mAb expression via gene-edited B cells $(126,127)$.

However, several lines of evidence suggests that ADA development, to a large extent, is dependent on the primary sequence of the $\mathrm{rAAV}$-delivered $\mathrm{mAb}$. First, $\mathrm{ADA}$ responses are not broad-spectrum, but selective (71). In a triple vector system in which $\mathrm{rAAV}$ encoding three different $\mathrm{mAbs}$ were delivered to the same non-human primates (NHPs), animals with low ADA response to one $\mathrm{mAb}$ can have high $\mathrm{ADA}$ response towards the other mAb (71). Second, eCD4-Ig, a modified fusion of CD4 and human IgG Fc, was markedly less immunogenic compared to rhesus-optimized anti-HIV bNAbs $(95,96)$. ADA responses against eCD4-Ig appeared around four weeks post-transduction and quickly reverted to baseline levels in three out of four NHPs by week 14, while ADA responses against bNAbs persisted until the bNAbs were cleared from the serum. And third, the magnitude of $\mathrm{ADA}$ responses in rhesus macaques was positively associated with the degree of sequence divergence from germline $\mathrm{V}$-genes and J-genes (87).

The Fc portion in therapeutic mAbs from non-human origin is thought to drive immunogenicity in human patients (128). However, humanized or fully human mAbs are also immunogenic during passive infusion. Similarly, rAAV-delivered rhesus-optimized anti-HIV bNAbs are immunogenic in rhesus macaques $(95,96)$. In one study, two murine mAb clones and one human $\mathrm{mAb}$ clone were packaged into the same rAAV construct and expressed by the same promoter (116). In recipient mice, the human mAb was expressed at much higher levels than the murine mAbs. While the reason for this observation is unclear, it is possible that the murine mAb-Fc portion might have caused an immune activation against itself, while the human $\mathrm{mAb}-\mathrm{Fc}$ portion was not as reactive. Alternatively, the $\mathrm{Fc}$ portion of an $\mathrm{mAB}$ may also potentially lead to complement activation and lysis of the rAAV-transduced cell $(93,129,130)$. Nevertheless, there is no experimental evidence that such events happen in vivo.

To mediate better bNAb expression, cyclosporin $A$, an immunosuppressant commonly used during transplantation, was administered to NHPs from 9 days to 28 days after rAAV8bNAb administration (94). This approach significantly increased average peak bNAb expression from $5 \mu \mathrm{g} / \mathrm{mL}$ to $38 \mu \mathrm{g} / \mathrm{mL}$, while preserving the capacity of bNAbs to prevent HIV-1 infection. Another method may be to take advantage of liver-induced 
TABLE 1 | List of AAV-vectored immunotherapeutic strategies.

\begin{tabular}{|c|c|c|c|c|c|}
\hline Pathogen & AAV serotype & Animal & Injection route & Therapeutic mode & References \\
\hline \multirow[t]{7}{*}{ HIV } & & Mouse & $\mathrm{IM}$ & bNAb & Lewis 2002 (91) \\
\hline & AAV2/8 & Mouse & $\mathrm{IM}$ & bNAb & Balazs 2011 (92) \\
\hline & AAV1 & Rh.M. & $\mathrm{IM}$ & bNAb-derived immunoadhesins & Johnson 2009 (93) \\
\hline & AAV1 & Rh.M. & $\mathrm{IM}$ & bNAb & Fuchs 2015 (70); Martinez-Navio 2019 (71) \\
\hline & AAV8 & Rh.M & $\mathrm{IM}$ & bNAb & Welles 2018 (88); Saunders 2015 (94) \\
\hline & AAV1 & Human & $\mathrm{IM}$ & bNAb & Priddy 2019 (89) \\
\hline & AAV1 & Rh.M. & $\mathrm{IM}$ & eCD4-lg & Gardner 2015 (95); 2019 (96) \\
\hline \multirow[t]{6}{*}{ Flu } & AAV2/8 & Mouse & $\mathrm{IM}$ & bNAb & Balazs $2013(97)$ \\
\hline & AAV9 & Mouse, Ferret & IN & bNAb & Limberis 2013a (98), 2013b (99); Adam 2014 (100) \\
\hline & AAV9 & Mouse & IN & Multi-domain Ab & Laursen 2018 (101) \\
\hline & AAV8 & Mouse & $\mathrm{IM}$ & Nanobody & Del Rosario 2020 (102) \\
\hline & AAV8 & Mouse & IV & 2CARD-MAVS & Nistal-Villán 2015 (103) \\
\hline & AAV9 & Mouse & IN & HAVantigen & Demminger 2020 (104) \\
\hline \multirow[t]{4}{*}{ SARS-CoV-1/2 } & AAV2 & Mouse & $\mathrm{IM}$ & RBD/antigen & Du 2006 (63) \\
\hline & AAV2 & Mouse & IN & RBD/antigen & Du $2008(105)$ \\
\hline & AAVrh32.33 & & $\mathrm{IM}$ & Spike/antigen & Vandenberghe and Freeman \\
\hline & Undisclosed & & IN & bNAb & Wilson \\
\hline \multirow[t]{4}{*}{ Malaria } & AAV1, AAV3 & Mouse & $\mathrm{IM}$ & MSP4/5/antigen & Logan 2007 (106) \\
\hline & AAV8 & Mouse & $\mathrm{IM}$ & $\mathrm{mAb}$ & Deal 2014 (107) \\
\hline & AdHu5/AAV1 & Mouse & $\mathrm{IM}$ & PfCSP/Pfs25/antigen & Yusuf 2019a (108), 2019b (109) \\
\hline & AAV8 & Mouse & IV & miR-155 & Hentzschel 2014 (110) \\
\hline \multirow[t]{3}{*}{$\mathrm{HCV}$} & AAV8 & Mouse & IV & NS5B/antigen & Mekonnen 2020 (111) \\
\hline & AAVrh32.33 & Mouse & $\mathrm{IM}$ & NS3/4/antigen & Zhu 2015 (112) \\
\hline & AAV8, AAVrh32.33 & Mouse & $\mathrm{IM}$ & E2/antigen & Zhu 2019 (113) \\
\hline \multirow[t]{2}{*}{ HPV/Cervical cancer } & AAV1 & Mouse & $\mathrm{IM}$ & E7/antigen & Zhou 2010 (114) \\
\hline & AAV5, AAV9 & Rh.M. & IN & L1/antigen & Nieto 2012 (115) \\
\hline \multirow[t]{3}{*}{ Ebola } & AAV9 & Mouse & $\mathrm{IM}, \mathrm{IN}$ & $\mathrm{mAb}$ & Limberis 2016 (116) \\
\hline & AAV9 & Mouse & $\mathrm{IV}, \mathrm{IM}, \mathrm{IN}$ & $m A b$ & Robert 2017 (117) \\
\hline & AAV6.2FF & Mouse & $\mathrm{IM}$ & $\mathrm{mAb}$ & van Lieshout 2018 (118) \\
\hline \multirow[t]{3}{*}{ Dengue } & AAV1 & Rh.M. & $\mathrm{IM}$ & $\mathrm{mAb}$ & Magnani 2017 (119) \\
\hline & AAVrh32.33, AAV8 & Mouse & $\mathrm{IM}$ & 79E/antigen & Li 2012 (120) \\
\hline & AAV6, AAV9 & Mouse & SC, IM & EDIII/antigen & Slon-Campos 2020 (121) \\
\hline \multirow[t]{3}{*}{ Prion } & AAV2 & Mouse & IC & mAb-derived scFv & Wuertzer 2008 (82) \\
\hline & AAV2 & Mouse & IC & mAb-derived scFv & Zuber 2008 (122) \\
\hline & AAV9 & Mouse & IC & mAb-derived scFv & Moda 2012 (123) \\
\hline Rabies & & Mouse & $\mathrm{IM}$ & G/antigen & Liu 2020 (124) \\
\hline Anthrax & Ad5/AAVrh.10 & Mouse & IV/Intrapleural & $m A b$ & De 2008 (30) \\
\hline RSV & Ad5/AAVrh.10 & Mouse & IV/Intrapleural & $m A b$ & Skaricic 2008 (28) \\
\hline
\end{tabular}

IM, intramuscular; IN, intranasal; IV, intravenous; SC, subcutaneous; IC, intracerebral; Rh.M., rhesus macaques.

tolerance of the transgene (131), which primarily results from nonconventional antigen presentation in the liver, causing $\mathrm{T}$ cell anergy, apoptosis, and T regulatory (Treg) cell expansion (132). A circumstantial piece of evidence that this strategy may work is that mAb delivery using rAAV8, a serotype with strong tropism in liver, demonstrated less frequent $\mathrm{ADA}$ formation than $\mathrm{mAb}$ delivery using rAAV1 ( 20\% ADA-positive in rAAV8 vectors vs. $>50 \%$ ADA-positive in rAAV1 vectors) $(87,88)$. However, there are too many experimental variables between the two studies and direct comparisons are not meaningful.

\section{Transgene Toxicity}

The delivery of antigens in the form of codon-optimized genes via a vectored approach will undeniably result in foreign antigen expression in injected or target tissues. Hypothetically, this may lead to inflammation-mediated immunotoxicity against the transduced host tissue. For LNP-vectored mRNAs, this concern is alleviated because mRNAs are inherently unstable and rapidly degraded (2). However, rAAVs are DNA vectors that are capable of mediating long-term antigen expression. To prevent potentially undesirable toxicity, the rAAV vector may be engineered to target specific cell types, such as muscle, without affecting others.

Another major risk is that mAbs are immunologically active molecules with the propensity to activate multiple inflammatory pathways that can mediate tissue damage. When they bind nonspecifically, they may cause unanticipated adverse events. Preclinical testing, such as passive administration and human tissue binding studies, can help to avert most of these issues. However, if off-target effects do occur in vivo, there is currently no effective method to control antibody transgene expression. As implicated in animal studies, rAAV-mediated mAb expression can persist for life following a single administration of rAAVs (71). In the event that $\mathrm{rAAV}$-mediated $\mathrm{mAb}$ is causing off-target toxicity, designing transgene expression cassettes with regulatory elements that can act as on/off switches might solve this problem. Several studies in mice and monkeys demonstrated that rAAV transgene expression levels may be controlled via small-molecule drugs (133-135). For example, the mAb may be placed under a 
rapamycin-regulated promoter (133). Another possibility is to inactivate $\mathrm{rAAV}$-delivered transgenes by destroying the vector DNA. This has been explored in the context of rAAV-mediated CRISPR-Cas9 delivery, in which a second rAAV encoding antiCas9 gRNA was able to reduce Cas9 expression (136).

\section{Pre-Existing Anti-rAAV Immunity}

In the context of infectious diseases, successful prevention programs rely on the establishment of herd immunity, whereby a large enough proportion of the population is immunized to cut off the spread of infections. However, preexisting immunity against AAV capsids significantly limits the pool of eligible recipients (137). Circulating NAbs against AAV serotypes can occur immediately following the disappearance of maternal antibodies $(138,139)$. Even low titers of pre-existing NAbs can negatively impact vector transduction (140-142). Capsid-specific $\mathrm{T}$ cell responses represent another major obstacle for rAAV vector transduction. Prior AAV infections have been proposed to elicit memory $\mathrm{T}$ cell responses against the virus $(143,144)$. These memory $\mathrm{CD}^{+} \mathrm{T}$ cell responses are more easily triggered than naive $\mathrm{CD}^{+} \mathrm{T}$ cells and were shown to eliminate host hepatocytes that were successfully transduced by rAAV vectors (141), resulting in reduced or absent transgene expression in clinical trials of rAAV gene therapies for muscle and liver-related genetic diseases $(143,145,146)$.

Some direct immunity-inhibiting strategies have been developed to overcome pre-existing immunity against the rAAV capsid, such as using plasmapheresis or IgG-degrading enzymes to remove pre-existing anti-AAV antibodies, or using rapamycin nanoparticles to reduce rAAV immunogenicity (147-149). Unfortunately, these strategies may not be suitable for rAAVmediated immunotherapy for infectious diseases, because these platforms require an intact immune system. Alternatively, structural modification of NAb recognition sites, directed evolution or rational engineering to generate novel capsids, rAAV epitope masking, chemical modifications, and injecting empty AAV capsids to act as decoys, may be viable evasion strategies against pre-existing immunity. These strategies have been described and reviewed elsewhere (23, 150-163). One potential complication is that, antigen-specific $\mathrm{CD}^{+} \mathrm{T}$ cells do not recognize the whole virion but only a short peptide sequence (typically 8 to 14 amino acids in length) presented by major histocompatibility molecule class I (164). Thus, a memory CD8 ${ }^{+}$ $\mathrm{T}$ cell clone that was induced by one AAV capsid might be crossreactive against another AAV capsid, if both capsids share the same peptide antigen recognized by the $\mathrm{CD} 8^{+} \mathrm{T}$ clone. Such possibilities, however, have only been demonstrated ex vivo (143). Lastly, administration of rAAV vectors via intramuscular, intranasal, or intracerebral routes might be able to reduce or prevent vector encounter with anti-capsid NAbs and T cells (Table 1).

\section{Immune Activation Against rAAV Transgenes}

In addition to the anti-AAV NAb and ADA mechanisms discussed above, adaptive immunity against rAAV-vectored immunotherapies can also be encountered in the form of antitransgene $\mathrm{CD}^{+}$and $\mathrm{CD} 8^{+} \mathrm{T}$ cell responses, which may result in inflammatory toxicities and other adverse events (165-173). On the other hand, immune activation might be a prerequisite if rAAV vectors are used as a delivery vehicle for vaccination against the delivered antigen.

Innate immunity against rAAVs is remarkably subdued as compared to other viral vectors, but the transgene cargo can be recognized by various pattern-recognition receptors (PRRs) (61). Toll-like receptor (TLR)9 recognizes unmethylated CpG DNA motifs in the genome cargo of rAAV vectors when they are exposed in endosomes and lysosomes, while TLR2 recognizes the AAV capsid. Both of these sensors lead to the activation of type 1 interferons via the MyD88 signaling pathway and play vital roles in shaping immune responses (174-182). To reduce TLR9 detection, CpG motifs may be removed from the rAAV cargo (176). More recently, short-noncoding DNA sequences that antagonize TLR9 activation were engineered into the vector genome to prevent the detection of the transgene DNA (183).

To control transgene-specific $\mathrm{T}$ cell responses, miRNAmediated regulation may be exploited to prevent transgene expression from antigen-presenting cells (APCs). For example, binding sites for myeloid-specific miRNA-142 can be engineered into the 3'-untranslated region of the transgene, so that its transcript is destroyed in APCs but not in other cell types (184, 185). Conversely, vectors based on AAVrh.32.33 can induce a robust $\mathrm{CD} 8 \mathrm{~T}$ cell response to the transgene product and has been used to express antigens for vaccination purposes (112, 113, 120, 186). Additionally, scAAV vectors induce stronger CD8 $\mathrm{T}$ cell responses and humoral responses against the transgene compared to corresponding ssAAV vectors (187).

\section{Manufacturing and Storage}

When deploying rAAV vectors to combat infectious diseases in a large portion of the world's total population, large production pipelines that can yield consistent quality will be required (188, 189). In addition, current manufacturing processes are prone to introducing empty and partially packaged vectors, thus reducing the purity and efficacy of the rAAV drug, while running the risk of causing deleterious immune activation (190). A standard for rAAV purity should be established, while major innovations in rAAV manufacturing is required. Once rAAV vectors are manufactured, they need to be properly stored to ensure their stabilities. Compared to LNP-mRNA vectors, which currently require stringent storage conditions $\left(-20^{\circ} \mathrm{C}\right.$ to $\left.-80^{\circ} \mathrm{C}\right)(13,14)$, rAAV vectors are generally stable for short periods at room temperature under typical laboratory conditions $(64,186)$. When distributed as vaccines or mAb carriers, rAAV vectors must confront shipment and handling hazards. Nevertheless, the stability of rAAV vectors might confer an advantage in areas of the world where cold-chain transport facilities are lacking.

\section{RAAV-BASED IMMUNOTHERAPIES IN DEVELOPMENT}

\section{HIV-1}

Despite the advent of antiretroviral therapies, HIV-1 continues to be a major threat to public health, with an estimated 38 million 
people living with HIV-1 infection and an additional 33 million deceased to date (191). HIV-1 is a lentivirus belonging to the Retroviridae family. It harbors two copies of its single-stranded RNA genome, enclosed inside an inner capsid structure and an outer lipid bilayer (192). This lipid bilayer is decorated with HIV envelope glycoproteins gp120/gp41, which use human CD4 as the main receptor, and either CCR5 or CXCR4 as coreceptors for virion attachment and membrane fusion (193). The error-prone nature of reverse transcription, coupled with host-restriction factor APOBEC3-mediated guanosine-to-adenosine mutations, and genomic recombination with other HIV strains, numerous mutations can be introduce into the HIV genome, resulting in antigenic drift, with the potential to evade immune recognition and impart drug resistance $(194,195)$. No vaccination regimen for HIV has been able to successfully induce bNAb responses. Additionally, HIV specifically targets CD4 T cells and CD4expressing monocytes, macrophages, dendritic cells, and microglial cells via its use of CD4, CCR5, and CXCR4 as receptors/coreceptors. The loss of these essential immune cell populations greatly impairs antiviral response. Finally, HIV can lay dormant inside the host genome without active gene transcription, thus, evading peptide presentation on MHC molecules and detection by T cells (192).

Developing protective humoral immunity against HIV-1 has been particularly challenging. Only bNAbs or antibody clones that recognize multiple strains of HIV-1 have the potential to overcome their high genomic variability (196). Second, each HIV-1 virion has only 4 to 35 glycoprotein Gp120/Gp41 trimer spikes on its surface, while a similarly sized influenza virus has $\sim 450$ spikes per virion (197). This means that the monomeric IgG may likely only binds to a single Gp120/Gp41 molecule via one of its two Fab arms (197). Thus, the bound IgG is easily detached as a result of its low avidity (197). To stabilize IgGGp120/Gp41 binding, the unbound Fab arm must bind to another molecule, usually the virion lipid bilayer or a host transmembrane protein that is incorporated into the envelop during budding and viral egress. This requires the HIV-1-bound IgG to be polyreactive, and in fact, many bNAbs do exhibit a certain degree of polyreactivity and self-reactivity (196). And third, HIV-1 directly impairs CD4 T cells, whose help is critical to proper B cell and antibody development (198). As a result, bNAbs only occur in a minority of HIV-1-infected individuals and only after several years into the infection. Passive infusion using a combination of bNAbs has been able to suppress viremia in HIV-infected patients and offers prophylaxis in simian models (199-201). However, different bNAbs have varied circulatory half-lives and repeated dosing is required, which is impractical. With combinatorial treatments using two bNAbs, the diminishing titer of one bNAb can drive virus evolution towards resistance to the other bNAb $(200,202)$.

The development of rAAV-based HIV immunotherapies has had mixed, yet promising success. For example, to achieve sustained HIV-1/SIV inhibition in a rhesus macaques model, simian Gp120-specific chimeric immunoadhesins 4L6 and 5L7 (made by fusing select Fabs to the Fc portion of simian IgG2) were packaged into rAAV1 vectors, and tested by IM delivery (93).
Four weeks after rAAV transduction, the macaques were challenged intravenously with a lethal dose of SIVmac316. Three out of three with rAAV1-4L6 and one out of three with rAAV1-5L7 were completely protected from infection. In another study, macaques were dosed with rAAV1 packaged with 4L6-IgG1 or 5L7-IgG1 transgenes, and then received six intravenous challenges at escalating doses with another SIV strain, SIVmac239 (70). Interestingly, one rAAV1-5L7-IgG1-tranduced animal resisted all six challenges, while the other animals presented lower viral loads and slower progression to peak viral loads, indicating that rAAV15L7-IgG1 was partially protective against SIVmac239. This partial efficacy could be explained by the fact that 5L7 conferred strong NK-dependent and antibody-dependent cellular cytotoxicity (ADCC) (70). In another study, rAAV8 vectors carrying anti-SIV mAbs ITS01 and ITS06.02 transgenes were co-administered into macaques by intramuscular injection in a dual vector approach. Animals later received repeated low-dose intrarectal challenge with SIVsmE660 (88). Approximately 90\% protection was achieved by these vectors. In a groundbreaking study, a cocktail of three different AAV1 vectors, each encoding a human HIV bNAb (10E8, 3BNC117, or 10-1074), was given to four macaques with preexisting SHIV (SIV-HIV amalgamation) viremia (71). Remarkably, this led to the complete suppression of viremia in a single animal within weeks of rAAV administration. This outcome was maintained throughout the course of the 240-week study, suggesting that a functional cure was achievable. These partial or complete successes in animal models have led to a phase I trial (NCT01937455), in which the HIV-1 bNAb PG9 was packaged into the AAV1 capsid and given to healthy humans at $4 \times 10^{12}$ to $1.2 \times 10^{14}$ vector genomes per subject (89). This approach was welltolerated, with only mild to moderate side effects that resolved without intervention. However, PG9 could not be detected in the volunteer sera, while anti-PG9 ADA was readily detected in 10 out of 16 volunteers. Only 2 out of 16 volunteers demonstrated neutralization activity against a small number of $\mathrm{HIV}-1$ isolates.

Since CD4 is the universal host receptor for all Gp120/Gp41 variants, one potential solution to counter all HIV-1 strains is to overexpress soluble forms of $\mathrm{CD} 4$, which act as decoys to saturate the CD4-binding site of Gp120/Gp41. One such attempt combined parts of CD4 to CCR5mim1, a sulfopeptide that binds CCR5- and CXCR4-tropic viruses. These domains are then fused to the human IgG1 Fc (95). This fusion protein, named eCD4-Ig, or its variants can neutralize a wide panel of HIV isolates, as well as several SIV isolates in vitro. The rhesus form of the transgene ( $r$ h-eCD4-Ig) was delivered intramuscularly by an AAV1 vector (AAV1-rh-eCD4-Ig) into macaques. Upon repeated IV challenge with SHIV-AD8, none of the vector-transduced animals became infected, even at the highest dose (95). AAV1-rheCD4-Ig-transduced macaques were also protected from infection by SIVmac239, of which the gp120/gp41 complex is highly divergent from SHIV-AD8 (96). Escalating doses of SIVmac239 eventually infected all AAV-rh-eCD4-Ig-transduced macaques, but the viruses also developed escape mutations that came with fitness costs. Nonetheless, the research for rAAV-based HIV vaccines is ongoing and further advancements are necessary to ensure these therapies are more efficacious. 


\section{Influenza}

Influenza infections are the seventh leading cause of death in the United States, with more than 20,000 fatalities recorded in the last year (203). Illnesses range from mild to severe, and even death. Hospitalization and death occur mainly among high risk groups. Individuals with a reduced capacity to mount an immune response upon infection have an increased susceptibility to influenza infections and complications, which include fatal pneumonia and acute respiratory distress syndrome (ARDS) (204). Vaccines are pivotal for influenza prevention, but their efficacies are substantially reduced in the elderly (205-207).

Unlike HIV-1, protective humoral immunity is easily generated against the flu virus by vaccination. However, the flu genome can undergo antigenic shift, a unique influenza virusassociated phenomena that poses additional difficulties (208). The influenza virus is made up of eight segmented negative-sense RNA strands enclosed inside a lipid bilayer that is studded by glycoproteins hemagglutinin (HA) and neuraminidase (NA). When the same organism is infected by multiple influenza subtypes, the RNA segments can be reshuffled to produce novel subtypes in a process called antigenic shift. In addition, influenza RNA polymerase is also highly error-prone, leading to the accumulation of mutations via antigenic drift (209).

Most antibodies produced in response to seasonal flu vaccines target the receptor binding site (RBS) within the globular HA-head region (210). Although functional against the vaccinated subtype, they can be rendered less effective by HA mutations and reshuffling. High-affinity bNAbs that can bind a broad array of influenza viruses have been isolated (211-214). They can offer protection by inhibiting fusion of the viral and cellular membranes (215-217), or by $\mathrm{Fc}$ receptor (FcR)-mediated mechanisms via ADCC (218). However, bNAbs usually target the more conserved regions of HA, which are less accessible than the globular head region and are thus more difficult to vaccinate against (215-217). Variable regions from the heavy and light chains of F10 and CR6261 bNAbs packaged into rAAV2/8 have been tested by administration into mice by intramuscular injection $(97,214,217,219)$. This treatment led to bNAb expression in mice within one week of rAAV administration, and protected mice against lethal influenza challenges with different H1N1 strains (97). Another study made a recombinant antibodylike molecule by fusing alpaca-derived single domain antibody (nanobody) to Fc domains (102). This construct named Rla-B6Fc was delivered using an rAAV8 vector via intramuscular injection, resulting in high-level transgene expression in sera for at least six months, and conferred complete protection against lethal H1N1 and H5N1 challenges.

Given that the respiratory tract is the primary target of influenza virus, the possibility of applying rAAV vectors intranasally has also been explored $(104,220)$. This administration route is thought to be superior. Intranasal delivery of rAAVs and its transgene product are targeted to nasal epithelia, and has the ability to circumvent preexisting anti-AAV immune responses, while providing passive immunization. As a proof-of-concept, a potent bNAb against various influenza A subtypes (FI6) $(98,99)$, was designed into an rAAV9 vector and delivered into mice and ferrets via intranasal distillation $(98,100)$. This afforded protection against several clinical isolates of $\mathrm{H} 5 \mathrm{~N} 1$ and $\mathrm{H} 1 \mathrm{~N} 1$, and provided partial protection in mice against clinical isolates of H7N9 (99). An alternative design packaging a humanized, multidomain recombinant antibody (MD3606) into an rAAV9 vector, protected mice against mouse-adapted influenza H1N1, H3N2, and B viruses following intranasal instillation (101). Investigation with NHPs and humans in clinical trials should provide insight into whether these approaches will be efficacious and more effective than conventional vaccines.

\section{Dengue}

Dengue viruses (DENVs) are members of the Flaviviridae family and are comprised of four distinct serotypes (DENV1-4) $(221,222)$. DENVs are enveloped and have a plus-stranded RNA genome. DENV infections may be asymptomatic or characterized as dengue fever (DF), dengue hemorrhagic fever (DHF), and dengue shock syndrome (DSS). There are approximately 3.9 billion people who are at risk of dengue virus infection around the world. Up to 390 million people are infected with dengue virus annually in over 100 endemic countries, with $70 \%$ of the actual burden being in Asia $(223,224)$. DENV is primarily caused by the spread of mosquito vectors and the growth of worldwide travel, and represents a significant global public health problem. Development of safe and effective immunotherapeutics and vaccines are thus a top priority that have yet to be met.

The major challenge for humoral immunity against dengue viruses (DENVs) is avoiding $\mathrm{ADE}$, where the presence of specific antibodies actually enhances DENV pathogenesis (225). The DENV coat is decorated with viral envelope (E) and membrane $(\mathrm{M})$ proteins $(221,222)$. Without pre-existing DENV antibodies, DENV E proteins bind to specific host cell receptors, leading to virus uncoating and genome release. Infection by one DENV serotype leads to production of antibodies that are cross-reactive with other serotypes. These cross-reactive antibodies do not neutralize DENV, but instead tag the virion for FcR-mediated endocytosis and productive infection (226). Several lines of evidence suggest that these cross-reactive antibodies can increase DENV disease severity. First, mAbs induced by DENVs can increase virus infection of FcR-bearing cells (227). Second, passive immunization of mice with DENV antibodies produced higher viremia following DENV infection, resulting in the death of the infected animals (228). And third, in human populations with high rates of DENV re-infections, the presence of low-titer DENV-specific antibodies is associated with a higher risk of severe disease when patients are infected with a different serotype $(229,230)$. These outcomes pose significant challenges to DENV vaccine development. As a matter of fact, Dengvaxia, the only licensed DENV vaccine, is only recommended in populations with prior DENV infections, as it is thought to increase dengue disease severity in naive individuals (231). On the other hand, re-infection with the same DENV serotype leads to efficient neutralization by pre-existing antibodies (232-235).

Given the nature of ADE in DENV immunotherapy, it may be feasible that a cocktail consisting of four AAV-mAb constructs, each encoding a recombinant antibody that can 
specifically neutralize one of the four DENV serotypes, may protect the host against all serotypes. In addition, the mAbs inside AAV-mAb constructs may be selected a priori, for those that lack ADE capacity. This precise strategy has not been attempted. Instead, anti-DENV3 NAb P3D05 was packaged in rAAV1 and delivered to macaques via intramuscular injection (119). Despite the high P3D05 expression that lasted for months, DENV3 infection, replication, and the development escape mutants were unaffected. Better understanding of the interactions between NAbs and DENVs, and screening of stronger NAbs are necessary to improve vector design and transduction outcomes.

\section{SARS-CoV-2}

COVID-19 emerged during the fall and winter of 2019 and was declared a global pandemic by the World Health Organization on March 11, $2020(236,237)$. As of February 27 ${ }^{\text {th }}, 2021$, more than 100 million people worldwide have been infected with SARS-CoV2 and more than two million deaths have been reported (238). SARS-CoV-2 is a coronavirus composed of a positive-sense RNA genome that is enclosed inside a lipid membrane, which is heavily studded by transmembrane S proteins (239). The S protein contains the receptor binding domain (RBD) and directly interacts with the host angiotensin-converting enzyme 2 (ACE2) receptor, which is essential for virus attachment and cell invasion $(239,240)$. Current vaccine development has focused on inducing antibody responses against the $S$ protein. However, previous studies on SARS-CoV, a virus with $\sim 80 \%$ sequence identity with SARS-CoV2, suggests that ADE induction may be a concern. Some studies have demonstrated that anti-S antibodies, or certain vaccine compositions, could increase virus uptake in macrophages, elevate pulmonary infiltration of proinflammatory cells, and exacerbate lung injury. Other studies have shown that immunization reduces viral load and protects the lung from severe damage (241-244).

After examining the available evidence from SARS-CoV and DENV studies, it appears that the key to avoiding ADE, while achieving antibody-mediated protection, is to generate highly specific NAbs at high doses without inducing low-potency antibodies that bind, but do not neutralize (12). To achieve this outcome, the vaccinating antigen must resemble the native antigen; hence, the majority of COVID-19 vaccine designs use the $\mathrm{S}-2 \mathrm{P}$ recombinant protein that contains two proline insertions to stabilize the vaccinating antigen (240). Two such designs, one by Pfizer/BioNTech and another by Moderna, demonstrated greater than $94 \%$ efficacy in phase III trials and are currently being distributed in the United States under emergency use (13, 14). The underlying mechanisms for achieving such high efficacies in these two vaccine compositions are still being investigated, but NAbs against SARS-CoV-2 are thought to play an important role (245-247).

Recently, an rAAV platform called AAVCOVID, which borrows from the same principle of expressing the $S$ protein antigen by packaging the SARS-CoV-2 $\mathrm{S}$ gene within an AAV capsid called AAVrh32.33 is being explored as an experimental vaccine $(186,248)$. The basis of the strategy relies on two previous findings. First, AAVrh32.33, a hybrid of two AAV natural capsid sequences isolated from rhesus macaque, has been shown to induce high antibody titers and potent CD8 $+\mathrm{T}$ cell responses in mice and non-human primates (249-251). And second, rAAV2 vector expressing the $\mathrm{RBD}$ of SARS-CoV, the virus responsible for the 2002 SARS epidemic, can induced sufficient neutralizing antibody against SARS-CoV infection with a single intramuscular injection (63). In addition, intranasal instillation can induce a strong local humoral response, and elicited stronger systemic and local specific cytotoxic $\mathrm{T}$ cell responses than intramuscular injections. Nevertheless, the protection against SARS-CoV challenge was comparable for both modes of administration (105).

Another immunotherapy strategy is to directly deliver a cocktail of neutralizing mAbs (casirivimab and imdevimab) that target different regions of the $\mathrm{RBD}$, in order to prevent further viral spread in patients (252-254). This method was recently granted an emergency use authorization by the FDA in certain high-risk patients with mild to moderate COVID-19 (255), and a phase I-III trial is ongoing to analyze its safety and efficacy (NCT04425629). The interim results suggest that intravenous and subcutaneous administration of the cocktail resulted in $\mathrm{mAb}$ presence for a month or more, was generally safe, and reduced viral loads in COVID-19 patients. Based on these preliminary results, research is underway to investigate whether intranasal administration of rAAVs carrying casirivimab and imdevimab can confer long-term $\mathrm{mAb}$ expression in the nasal mucosa for prophylaxis against COVID-19 (256).

\section{Prion Disease}

Prion diseases, or transmissible spongiform encephalopathies (TSEs), are caused by the misfolding of the normal cellular prion protein $\left(\mathrm{PrP}^{\mathrm{C}}\right)$ into the abnormal pathogenic scrapie isoform $\left(\mathrm{PrP}^{\mathrm{Sc}}\right)$, or simply prions (257). Unlike $\operatorname{PrP}^{\mathrm{C}}$, prions are resistant to protease digestion and are capable of converting normal $\mathrm{PrP}^{\mathrm{C}}$ into more prions. Prion accumulation primarily affects the central nervous system (CNS) and leads to a series of neurological degenerative disorders that inexorably ends in death. Drug development for prion diseases is challenging, because in order to gain access to prions, the drugs must cross the blood brain barrier to efficiently reach the CNS. It has been demonstrated that anti- $\mathrm{PrP}^{\mathrm{C}} \mathrm{mAbs}$ could protect the normal $\mathrm{PrP}^{\mathrm{C}}$ from interacting with the pathogenic prion and slow disease progression $(258,259)$. However, these antibodies and other compounds typically show limited efficacy in long-term animal studies. This failure is likely due to host tolerance to endogenous $\mathrm{PrP}^{\mathrm{C}}$ and poor antibody diffusion into neuronal tissues (260-264).

The natural tropism of certain AAV serotypes towards the CNS presents a huge advantage for $\mathrm{AAAV}$-vectored $\mathrm{mAb}$ delivery (265). To this end, several studies have tested rAAV vectors that deliver scFv proteins via the intracerebral route $(82,122,123$, 266). These scFvs were made by fusing the variable regions of the heavy and light chains of an $\mathrm{mAb}$ clone, which preserved the antigen-recognition capacity of the original mAb, but lacks Fcmediated function. Intracerebral delivery of rAAV2 or rAAV9packaged scFvs that binds to $\operatorname{PrP}^{\mathrm{C}}$ can delay prion disease onset in mice $(82,123)$. An rAAV2 vector that delivers scFvs against the laminin receptor, which interacts with both $\operatorname{PrP}^{\mathrm{C}}$ and prions, also delayed onset of prion pathogenesis and decreased $\mathrm{PrP}^{\mathrm{Sc}}$ 
burden in the CNS of mice $(82,122,123,266)$. Further studies are needed to assess the translatability of the platform in humans.

\section{Filoviruses}

Filoviruses, which include Ebola virus, Marburg virus, and others, are notable for their capacity to cause highly lethal infections in humans (267). A live attenuated vaccine, tradenamed Ervebo, is available for Zaire ebolavirus, a highly pathogenic strain of Ebola (268). This vaccine consists of a pseudotyped vesicular-stomatitis virus (VSV) that expresses Zaire ebolavirus glycoprotein (GP) and has near 100\% efficacy. However, no vaccines are yet available for other filoviruses, which tend to cause sporadic outbreaks and lack exhaustive study (269). Furthermore, no targeted treatments are available for patients with symptomatic infections.

Several studies have demonstrated that $\mathrm{mAbs}$ raised against the surface glycoprotein (GP) of Zaire ebolavirus are capable of protecting experimental animals from lethal Ebola virus infections within a therapeutic window of three days prechallenge to five days post-challenge (270-273). In light of these findings, several groups examined whether rAAV vectors can be used to deliver long-lasting Ebola-specific mAbs for durable prophylaxis and therapeutics. Zaire ebolavirus GPrecognizing mAbs were designed into rAAV9 vectors and delivered into mice via intramuscular, intravenous, or intranasal routes. Vector-treated animals showed rescue and longer survival from lethal Ebola challenges than animals subjected to $\mathrm{mAb}$ infusion $(116,117)$. Injection by intravenous and intramuscular routes offered better protection against Ebola virus as compared to intranasal administration, and the level of protection significantly increased with vector dose. Notably, an AAV6 variant, called AAV6.2FF, was used to package Ebolaspecific mAbs (118). In this study, treatment with a single vector rAAV6.2FF-mAb clone presented $83 \%$ to $100 \%$ efficiency, while a dual therapy using two vectored $\mathrm{mAb}$ clones resulted in complete protection. The protective effect lasted for at least five months after a single rAAV6.2FF-mAb administration. However, treatment with a seven-day lead time was required for complete protection, suggesting that this method of $\mathrm{mAb}$ delivery may be too delayed for treating patients with symptoms, since the entire disease course spans only 14 to 21 days (274).

\section{Anthrax and RSV}

Some pathogens require a rapid response to block progression of the disease. To promote rapid transgene expression, one strategy is to use a dual-vector approach with an initial AdV treatment to mediate rapid expression, followed by an rAAV vector to mediate long-lasting expression. This formulation is explored in treating infections by $B$. anthracis, a potential bioweapon in terrorist attacks (275), and in RSV, a common cause of respiratory disease in infants and adults (276).

Antibodies against anthrax protective antigen (PA) are effective at inhibiting anthrax lethal toxin (LT)-mediated damage (277). To achieve rapid inhibition of toxin, a dual-vector platform comprising of recombinant anti-PA antibody packaged into Ad5 and AAVrh.10 vectors was developed (30). The Ad5-anti-PA and AAVrh.10-anti-PA vectors were then administered into mice via intravenous and intrapleural injection routes, respectively. While Ad5-anti-PA conferred complete protection against LT challenge between one day and eight weeks post-injection, the AAVrh.10anti-PA conferred complete protection against LT challenge from two weeks to 26 weeks. When both vectors were given together, complete protection was observed from day 1 to week 26 post-injection.

The dual-vector strategy for RSV utilizes the murine form of the anti-RSV drug palivizumab (28). While intravenous injection of Ad5-anti-RSV $\mathrm{mAb}$ produced high $\mathrm{mAb}$ titers at three days postadministration, intrapleural injection of AAVrh.10-anti-RSV mAb took four to eight weeks to reach high $\mathrm{mAb}$ titers in the serum, but reduced RSV viral load for at least 21 weeks post-injection.

\section{Malaria}

Malaria presents many unique challenges for vaccine development (278). Malaria is caused by many species of parasites within the genus Plasmodium. These parasites, particularly $P$. falciparum, undergo complex life cycles that transmit between humans and mosquitos, and between different host tissue types (279). All of these features increase antigen diversity and pose difficulties for vaccine target selection. For reasons not completely understood, memory B cells against malaria do not persist very long in either natural infections or in vaccination attempts, resulting in the lack of persistent humoral immunity and repeated infections (280-282).

To overcome the inability for humans to retain humoral immunity towards P. falciparum, rAAV vectors can be used to mediate long-term expression of the malarial antigens, thus enabling continued stimulation of the immune system. Given that AAVs naturally have low immunogenicity, AdV formulations may be added to improve the immune response raised against the parasite. For example, in a dual-vector strategy, Ad5 and rAAV1 were co-packaged with the $P$. falciparum circumsporozoite protein (PfCSP) and its sexual stage P25 protein (Pfs25). PfCSP is relatively conserved across different Plasmodium species, while immunity against Pfs25 is thought to block transmission (283). The Ad5- $P f$ s25-PfCSP vector was given to mice via intramuscular injection, followed by AAV1-Pfs25-PfCSP vector six weeks later (108). The dual-vectored Ad5-prime/AAV1-boost regimen was highly effective in mice for both full protection and transmissionblocking activity against transgenic $P$. berghei parasites expressing the corresponding P. falciparum antigens (108). Remarkably, antibody responses raised in this manner were sustained for over nine months after boosting, and maintained high levels of transmission-reducing activity $(108,109)$.

Alternatively, rAAV vectors are capable of mediating $\mathrm{mAb}$ expression outside of B cells, thus escaping malaria-mediated B cell suppression. To show this ability, rAAV2 vectors expressing human mAbs against PfCSP were delivered to mice via intramuscular injection (107). This method offered sterile immunity against the rodent Plasmodium berghei strain via mosquito bites in all mice that expressed $1 \mathrm{mg} / \mathrm{mL}$ or more of the mAb. Expression of $\mathrm{mAb}$ also lasted for 8 to 11 weeks, or at the end points of the experiment. It remains to be determined whether $\mathrm{rAAV}$-delivered recombinant $\mathrm{mAbs}$ can persist longer than naturally formed anti-malaria mAbs. 


\section{HCV}

$\mathrm{HCV}$ is a single-stranded, positive-sense RNA virus that uses an error-prone RNA polymerase for genome replication (284). This feature results in high inter-host and intra-host genetic variability that limits the effectiveness of humoral immunity. The nonstructural proteins of $\mathrm{HCV}$ contain several highly conserved regions with potential to act as vaccine epitopes (285). Intravenous injections of rAAV expressing NS5B in mice elicit strong and durable intrahepatic, NS5B-specific, CD8 T cell activation (111). Additionally, rAAVrh32.33 packaged with the HCV E2 envelope protein can elicit a strong antibody response, while rAAVrh32.33 packaged with HCV NS3 or NS3/4 can elicit both antibody and cellular responses $(112,113)$. Further studies are needed to assess whether these strategies are effective in protecting against HCV infection in NHP models and human subjects.

\section{Rabies}

Rabies is a severe infection of the CNS that is always nearly fatal. It is caused by zoonotic viruses that belong to the Lyssavirus genus, the most common member being rabies virus (RABV). RABV is responsible for the majority of rabies infections in humans (286). Vaccines and antisera are effective at preventing disease onset following RABV exposure (287). However, in areas where rabies is still endemic, awareness and accessibility to these preventative measures are limited (288). Furthermore, no cure is available once symptoms start to appear. Hence, there is an urgent need to develop prophylactic and treatment regimen against RABV.

Hypothetically, the strong tropism of certain rAAV serotypes toward the nervous system might allow rAAV-mediated delivery of therapeutic mAbs to the RABV-affected tissues. This possibility has not been extensively explored for the treatment of rabies. An attempt to use rAAVs for immunization against RABV was performed in mice (124). In this work, rAAVs containing glycoproteins from various strains of RABV (rAAV-G) were administered via intramuscular injection. All rAAV-G treatments induced higher neutralizing antibody titers and cytokine responses than the attenuated RABV vaccine LBNSE-GMCSF. Furthermore, rAAV-G protected mice from intracerebral challenges of RABV for nine months post-administration. It is unclear whether rAAV-G can offer protection against RABV post-exposure.

\section{Human Papillomavirus (HPV)}

Chronic infection by HPV subtypes 16 and 18 are the strongest risk factors for cervical cancer development $(289,290)$. While vaccines are available to prevent new infections, no cure is present for existing infections. HPV-mediated oncogenesis is driven by the viral proteins E6 and E7. They inhibit tumor suppressor proteins $\mathrm{p} 53$ and $\mathrm{Rb}$, leading to the arrest of proliferating cells at the DNA synthesis and growth phases of the cell cycle (291-293). This action increases the risk of genomic instability and malignant transformation of host cells (290). Thus, HPV E6 and E7 are being used as vaccination targets. Intramuscular administration of rAAV1 packaged with the E7 and heat shock protein 70 (hsp70) fusion protein (rAAV11618E7hsp70) completely protected mice from challenge by E7-expressing tumor cell lines at 5, 12, and 24 weeks posttreatment (114). In addition, when the rAAV1-E7 vector was given eight to ten days after tumor inoculation, the size of the pre-established tumor was significantly reduced. An alternative strategy is to target the HPV major capsid protein L1. rAAV5 and rAAV9 packaged with HPV16 L1 was administered to rhesus macaques via intranasal delivery (115). By using rAAV5-HPV16-L1 as the prime vector and rAAV9-HPV16-L1 as the boosting vector, neutralizing antibodies were elicited in four out of six animals and mediated protection for seven months post-immunization. This effect was achieved even in the presence of pre-existing anti-AAV9 antibodies.

\section{CONCLUDING REMARKS AND FUTURE DIRECTIONS}

The ability to deliver gene expression cassettes in vivo has greatly expanded the toolbox to combat infectious diseases. With rAAVmediated gene delivery, expression of antigens or therapeutic molecules may be achieved and maintained for long periods. Current studies demonstrated that this approach could prophylactically prevent new infections, with the additional possibility of eliminating existing infections in animal models. However, rAAV-mediated immunotherapy is still in its infancy, with many issues to be solved. Future studies are warranted to address several key questions. First, ADAs toward therapeutic $\mathrm{mAbs}$ and Ig derivatives are currently the biggest obstacle to long-term $\mathrm{mAb}$ expression from the host, but the underlying mechanisms of ADA development are largely a mystery. Elucidating these mechanisms will be critical to the design of rAAV immunotherapeutics that are capable of overcoming ADAs. Second, pre-existing immunity to the rAAV capsid and the transgene prevents a large portion of the world's population from gaining access to AAV-vectored immunotherapies. Strategies to evade pre-existing anti-rAAV immunity without compromising anti-pathogen immunity need to be devised. Third, given the fact that $\mathrm{AAA}$ can mediate long-term transgene expression, even when the transgene is no longer desired, regulatable immunotherapies ought to be developed to further ensure patient safety. Fourth, novel capsids should be explored in the context of immunotherapy. And finally, the manufacturing process requires major improvement for deploying rAAV vectors in global distributions efforts.

\section{AUTHOR CONTRIBUTIONS}

WZ and MM wrote the initial draft of the manuscript. WZ, MM, PT, and GG revised and finalized the manuscript. All authors contributed to the article and approved the submitted version.

\section{FUNDING}

This work was supported by grants from the University of Massachusetts Medical School (an internal grant) and by the NIH (R01NS076991-01, P01HL131471-02, UG3HL147367-01, R01HL097088, U19 AI149646-01). 


\section{REFERENCES}

1. Pollard AJ, Bijker EM. A Guide to Vaccinology: From Basic Principles to New Developments. Nat Rev Immunol (2021) 21:83-100. doi: 10.1038/ s41577-020-00479-7

2. Rauch S, Jasny E, Schmidt KE, Petsch B. New Vaccine Technologies to Combat Outbreak Situations. Front Immunol (2018) 9:1963. doi: 10.3389/ fimmu.2018.01963

3. Leitner T, Halapi E, Scarlatti G, Rossi P, Albert J, Fenyo EM, et al. Analysis of Heterogeneous Viral Populations by Direct DNA Sequencing. Biotechniques (1993) 15(1):120-7.

4. Wolfs TF, Zwart G, Bakker M, Goudsmit J. HIV-1 Genomic RNA Diversification Following Sexual and Parenteral Virus Transmission. Virology (1992) 189(1):103-10. doi: 10.1016/0042-6822(92)90685-I

5. Maartens G, Celum C, Lewin SR. HIV Infection: Epidemiology, Pathogenesis, Treatment, and Prevention. Lancet (2014) 384(9939):25871. doi: 10.1016/S0140-6736(14)60164-1

6. Messaoudi I, Amarasinghe GK, Basler CF. Filovirus Pathogenesis and Immune Evasion: Insights From Ebola Virus and Marburg Virus. Nat Rev Microbiol (2015) 13(11):663-76. doi: 10.1038/nrmicro3524

7. Blair HA. Ibalizumab: A Review in Multidrug-Resistant Hiv-1 Infection. Drugs (2020) 80(2):189-96. doi: 10.1007/s40265-020-01258-3

8. Lu RM, Hwang YC, Liu IJ, Lee CC, Tsai HZ, Li HJ, et al. Development of Therapeutic Antibodies for the Treatment of Diseases. J BioMed Sci (2020) 27(1):1. doi: 10.1186/s12929-019-0592-Z

9. Salazar G, Zhang N, Fu TM, An Z. Antibody Therapies for the Prevention and Treatment of Viral Infections. NPJ Vaccines (2017) 2:19. doi: 10.1038/ s41541-017-0019-3

10. Kyriakidis NC, Lopez-Cortes A, Gonzalez EV, Grimaldos AB, Prado EO. Sars-CoV-2 Vaccines Strategies: A Comprehensive Review of Phase 3 Candidates. NPJ Vaccines (2021) 6(1):28. doi: 10.1038/s41541-021-00292-w

11. Wang M, Jiang S, Wang Y. Recent Advances in the Production of Recombinant Subunit Vaccines in Pichia Pastoris. Bioengineered (2016) 7 (3):155-65. doi: 10.1080/21655979.2016.1191707

12. Lee WS, Wheatley AK, Kent SJ, DeKosky BJ. Antibody-Dependent Enhancement and SARS-CoV-2 Vaccines and Therapies. Nat Microbiol (2020) 5(10):1185-91. doi: 10.1038/s41564-020-00789-5

13. Polack FP, Thomas SJ, Kitchin N, Absalon J, Gurtman A, Lockhart S, et al. Safety and Efficacy of the BNT162b2 Mrna Covid-19 Vaccine. N Engl J Med (2020) 383(27):2603-15. doi: 10.1056/NEJMoa2034577

14. Baden LR, El Sahly HM, Essink B, Kotloff K, Frey S, Novak R, et al. Efficacy and Safety of the Mrna-1273 SARS-CoV-2 Vaccine. N Engl J Med (2021) 384:403-16. doi: 10.1056/NEJMoa2035389

15. Sung YK, Kim SW. Recent Advances in the Development of Gene Delivery Systems. Biomater Res (2019) 23:8. doi: 10.1186/s40824-019-0156-Z

16. Williams MR, Fricano-Kugler CJ, Getz SA, Skelton PD, Lee J, Rizzuto CP, et al. A Retroviral Crispr-Cas9 System for Cellular Autism-Associated Phenotype Discovery in Developing Neurons. Sci Rep (2016) 6:25611. doi: $10.1038 /$ srep25611

17. Park A, Hong P, Won ST, Thibault PA, Vigant F, Oguntuyo KY, et al. Sendai Virus, an RNA Virus With No Risk of Genomic Integration, Delivers CRISPR/Cas9 for Efficient Gene Editing. Mol Ther Methods Clin Dev (2016) 3:16057. doi: 10.1038/mtm.2016.57

18. Hindriksen S, Bramer AJ, Truong MA, Vromans MJM, Post JB, VerlaanKlink I, et al. Baculoviral Delivery of CRISPR/Cas9 Facilitates Efficient Genome Editing in Human Cells. PloS One (2017) 12(6):e0179514. doi: 10.1371/journal.pone.0179514

19. Lauer KB, Borrow R, Blanchard TJ. Multivalent and Multipathogen Viral Vector Vaccines. Clin Vaccine Immunol (2017) 24(1). doi: 10.1128/ CVI.00298-16

20. Warnock JN, Daigre C, Al-Rubeai M. Introduction to Viral Vectors. Methods Mol Biol (2011) 737:1-25. doi: 10.1007/978-1-61779-095-9_1

21. Tatsis N, Ertl HC. Adenoviruses as Vaccine Vectors. Mol Ther (2004) 10 (4):616-29. doi: 10.1016/j.ymthe.2004.07.013

22. Ricobaraza A, Gonzalez-Aparicio M, Mora-Jimenez L, Lumbreras S, Hernandez-Alcoceba R. High-Capacity Adenoviral Vectors: Expanding the Scope of Gene Therapy. Int J Mol Sci (2020) 21(10). doi: 10.3390/ ijms21103643
23. Bulcha JT, Wang Y, Ma H, Tai PWL, Gao G. Viral Vector Platforms Within the Gene Therapy Landscape. Signal Transduct Target Ther (2021) 6(1):53. doi: 10.1038/s41392-021-00487-6

24. Zhu FC, Guan XH, Li YH, Huang JY, Jiang T, Hou LH, et al. Immunogenicity and Safety of a Recombinant Adenovirus Type-5Vectored COVID-19 Vaccine in Healthy Adults Aged 18 Years or Older: A Randomised, Double-Blind, Placebo-Controlled, Phase 2 Trial. Lancet (2020) 396(10249):479-88. doi: 10.1016/S0140-6736(20)31605-6

25. Voysey M, Clemens SAC, Madhi SA, Weckx LY, Folegatti PM, Aley PK, et al. Safety and Efficacy of the ChAdOx1 nCoV-19 Vaccine (AZD1222) Against SARS-CoV-2: An Interim Analysis of Four Randomised Controlled Trials in Brazil, South Africa, and the UK. Lancet (2021) 397(10269):99-111. doi: 10.1016/S0140-6736(20)32661-1

26. Sadoff J, Le Gars M, Shukarev G, Heerwegh D, Truyers C, de Groot AM, et al. Interim Results of a Phase 1-2a Trial of Ad26.COV2.S Covid-19 Vaccine. N Engl J Med (2021). doi: 10.1056/NEJMoa2034201

27. Lee CS, Bishop ES, Zhang R, Yu X, Farina EM, Yan S, et al. AdenovirusMediated Gene Delivery: Potential Applications for Gene and Cell-Based Therapies in the New Era of Personalized Medicine. Genes Dis (2017) 4 (2):43-63. doi: 10.1016/j.gendis.2017.04.001

28. Skaricic D, Traube C, De B, Joh J, Boyer J, Crystal RG, et al. Genetic Delivery of an anti-RSV Antibody to Protect Against Pulmonary Infection With RSV. Virology (2008) 378(1):79-85. doi: 10.1016/j.virol.2008.04.016

29. Tutykhina IL, Sedova ES, Gribova IY, Ivanova TI, Vasilev LA, Rutovskaya MV, et al. Passive Immunization With a Recombinant Adenovirus Expressing an HA (H5)-Specific Single-Domain Antibody Protects Mice From Lethal Influenza Infection. Antiviral Res (2013) 97(3):318-28. doi: 10.1016/j.antiviral.2012.12.021

30. De BP, Hackett NR, Crystal RG, Boyer JL. Rapid/Sustained Anti-Anthrax Passive Immunity Mediated by Co-Administration of Ad/AAV. Mol Ther (2008) 16(1):203-9. doi: 10.1038/sj.mt.6300344

31. Buchbinder SP, Mehrotra DV, Duerr A, Fitzgerald DW, Mogg R, Li D, et al. Efficacy Assessment of a Cell-Mediated Immunity HIV-1 Vaccine (the Step Study): A Double-Blind, Randomised, Placebo-Controlled, Test-of-Concept Trial. Lancet (2008) 372(9653):1881-93. doi: 10.1016/S0140-6736(08)61591-3

32. McElrath MJ, De Rosa SC, Moodie Z, Dubey S, Kierstead L, Janes H, et al HIV-1 Vaccine-Induced Immunity in the Test-of-Concept Step Study: A Case-Cohort Analysis. Lancet (2008) 372(9653):1894-905. doi: 10.1016/ S0140-6736(08)61592-5

33. Hammer SM, Sobieszczyk ME, Janes H, Karuna ST, Mulligan MJ, Grove D, et al. Efficacy Trial of a DNA/rAd5 HIV-1 Preventive Vaccine. N Engl J Med (2013) 369(22):2083-92. doi: 10.1056/NEJMoa1310566

34. Dull T, Zufferey R, Kelly M, Mandel RJ, Nguyen M, Trono D, et al. A ThirdGeneration Lentivirus Vector With a Conditional Packaging System. J Virol (1998) 72(11):8463-71. doi: 10.1128/JVI.72.11.8463-8471.1998

35. Naldini L, Blomer U, Gallay P, Ory D, Mulligan R, Gage FH, et al. In Vivo Gene Delivery and Stable Transduction of Nondividing Cells by a Lentiviral Vector. Science (1996) 272(5259):263-7. doi: 10.1126/science.272.5259.263

36. Kumar M, Keller B, Makalou N, Sutton RE. Systematic Determination of the Packaging Limit of Lentiviral Vectors. Hum Gene Ther (2001) 12(15):1893905. doi: 10.1089/104303401753153947

37. Mullard A. Second Anticancer CAR T Therapy Receives FDA Approval. Nat Rev Drug Discovery (2017) 16(12):818. doi: 10.1038/nrd.2017.249

38. Li C, Samulski RJ. Engineering Adeno-Associated Virus Vectors for Gene Therapy. Nat Rev Genet (2020) 21(4):255-72. doi: 10.1038/s41576-0190205-4

39. Vandendriessche T, Thorrez L, Acosta-Sanchez A, Petrus I, Wang L, Ma L, et al. Efficacy and Safety of Adeno-Associated Viral Vectors Based on Serotype 8 and 9 vs. Lentiviral Vectors for Hemophilia B Gene Therapy. J Thromb Haemost (2007) 5(1):16-24. doi: 10.1111/j.1538-7836.2006.02220.x

40. Harvey AR, Kamphuis W, Eggers R, Symons NA, Blits B, Niclou S, et al. Intravitreal Injection of Adeno-Associated Viral Vectors Results in the Transduction of Different Types of Retinal Neurons in Neonatal and Adult Rats: A Comparison With Lentiviral Vectors. Mol Cell Neurosci (2002) 21(1):141-57. doi: 10.1006/mcne.2002.1168

41. Wolf DA, Banerjee S, Hackett PB, Whitley CB, McIvor RS, Low WC. Gene Therapy for Neurologic Manifestations of Mucopolysaccharidoses. Expert Opin Drug Delivery (2015) 12(2):283-96. doi: 10.1517/17425247.2015.966682 
42. Joglekar AV, Sandoval S. Pseudotyped Lentiviral Vectors: One Vector, Many Guises. Hum Gene Ther Methods (2017) 28(6):291-301. doi: 10.1089/ hgtb.2017.084

43. Ortinski PI, O'Donovan B, Dong X, Kantor B. Integrase-Deficient Lentiviral Vector as an All-in-One Platform for Highly Efficient CRISPR/Cas9Mediated Gene Editing. Mol Ther Methods Clin Dev (2017) 5:153-64. doi: 10.1016/j.omtm.2017.04.002

44. Rio P, Banos R, Lombardo A, Quintana-Bustamante O, Alvarez L, Garate Z, et al. Targeted Gene Therapy and Cell Reprogramming in Fanconi Anemia. EMBO Mol Med (2014) 6(6):835-48. doi: 10.15252/emmm.201303374

45. Cai Y, Bak RO, Mikkelsen JG. Targeted Genome Editing by Lentiviral Protein Transduction of Zinc-Finger and TAL-effector Nucleases. Elife (2014) 3:e01911. doi: 10.7554/eLife.01911

46. Choi JG, Dang Y, Abraham S, Ma H, Zhang J, Guo H, et al. Lentivirus PrePacked With Cas9 Protein for Safer Gene Editing. Gene Ther (2016) 23 (7):627-33. doi: 10.1038/gt.2016.27

47. Balakrishnan B, Jayandharan GR. Basic Biology of Adeno-Associated Virus (AAV) Vectors Used in Gene Therapy. Curr Gene Ther (2014) 14(2):86-100. doi: 10.2174/1566523214666140302193709

48. Wang D, Tai PWL, Gao G. Adeno-Associated Virus Vector as a Platform for Gene Therapy Delivery. Nat Rev Drug Discovery (2019) 18(5):358-78. doi: 10.1038/s41573-019-0012-9

49. Ogden PJ, Kelsic ED, Sinai S, Church GM. Comprehensive AAV Capsid Fitness Landscape Reveals a Viral Gene and Enables Machine-Guided Design. Science (2019) 366(6469):1139-43. doi: 10.1126/science.aaw2900

50. Schnepp BC, Clark KR, Klemanski DL, Pacak CA, Johnson PR. Genetic Fate of Recombinant Adeno-Associated Virus Vector Genomes in Muscle. J Virol (2003) 77(6):3495-504. doi: 10.1128/JVI.77.6.3495-3504.2003

51. Deyle DR, Russell DW. Adeno-Associated Virus Vector Integration. Curr Opin Mol Ther (2009) 11(4):442-7.

52. Duan D, Sharma P, Yang J, Yue Y, Dudus L, Zhang Y, et al. Circular Intermediates of Recombinant Adeno-Associated Virus Have Defined Structural Characteristics Responsible for Long-Term Episomal Persistence in Muscle Tissue. J Virol (1998) 72(11):8568-77. doi: 10.1128/ JVI.72.11.8568-8577.1998

53. Buchlis G, Podsakoff GM, Radu A, Hawk SM, Flake AW, Mingozzi F, et al. Factor IX Expression in Skeletal Muscle of a Severe Hemophilia B Patient 10 Years After AAV-mediated Gene Transfer. Blood (2012) 119(13):3038-41. doi: 10.1182/blood-2011-09-382317

54. Schnepp BC, Jensen RL, Chen CL, Johnson PR, Clark KR. Characterization of Adeno-Associated Virus Genomes Isolated From Human Tissues. J Virol (2005) 79(23):14793-803. doi: 10.1128/JVI.79.23.14793-14803.2005

55. Nguyen GN, Everett JK, Kafle S, Roche AM, Raymond HE, Leiby J, et al. A Long-Term Study of AAV Gene Therapy in Dogs With Hemophilia A Identifies Clonal Expansions of Transduced Liver Cells. Nat Biotechnol (2021) 39(1):47-55. doi: 10.1038/s41587-020-0741-7

56. Ellis BL, Hirsch ML, Barker JC, Connelly JP, Steininger RJ,3, Porteus MH. A Survey of Ex Vivo/In Vitro Transduction Efficiency of Mammalian Primary Cells and Cell Lines With Nine Natural Adeno-Associated Virus (AAV1-9) and One Engineered Adeno-Associated Virus Serotype. Virol J (2013) 10:74. doi: 10.1186/1743-422X-10-74

57. Khan IF, Hirata RK, Wang PR, Li Y, Kho J, Nelson A, et al. Engineering of Human Pluripotent Stem Cells by AAV-mediated Gene Targeting. Mol Ther (2010) 18(6):1192-9. doi: 10.1038/mt.2010.55

58. Dai X, Park JJ, Du Y, Kim HR, Wang G, Errami Y, et al. One-Step Generation of Modular CAR-T Cells With AAV-Cpf1. Nat Methods (2019) 16(3):247-54. doi: 10.1038/s41592-019-0329-7

59. Shirley JL, de Jong YP, Terhorst C, Herzog RW. Immune Responses to Viral Gene Therapy Vectors. Mol Ther (2020) 28(3):709-22. doi: 10.1016/ j.ymthe.2020.01.001

60. Nidetz NF, McGee MC, Tse LV, Li C, Cong L, Li Y, et al. Adeno-Associated Viral Vector-Mediated Immune Responses: Understanding Barriers to Gene Delivery. Pharmacol Ther (2020) 207:107453. doi: 10.1016/j.pharmthera.2019.107453

61. Muhuri M, Maeda Y, Ma H, Ram S, Fitzgerald KA, Tai PW, et al. Overcoming Innate Immune Barriers That Impede AAV Gene Therapy Vectors. J Clin Invest (2021) 131(1). doi: 10.1172/JCI143780

62. Nieto K, Salvetti A. Aav Vectors Vaccines Against Infectious Diseases. Front Immunol (2014) 5:5. doi: 10.3389/fimmu.2014.00005
63. Du L, He Y, Wang Y, Zhang H, Ma S, Wong CK, et al. Recombinant AdenoAssociated Virus Expressing the Receptor-Binding Domain of Severe Acute Respiratory Syndrome Coronavirus S Protein Elicits Neutralizing Antibodies: Implication for Developing SARS Vaccines. Virology (2006) 353(1):6-16. doi: 10.1016/j.virol.2006.03.049

64. Gruntman AM, Su L, Su Q, Gao G, Mueller C, Flotte TR. Stability and Compatibility of Recombinant Adeno-Associated Virus Under Conditions Commonly Encountered in Human Gene Therapy Trials. Hum Gene Ther Methods (2015) 26(2):71-6. doi: 10.1089/hgtb.2015.040

65. Manning WC, Paliard X, Zhou S, Pat Bland M, Lee AY, Hong K, et al. Genetic Immunization With Adeno-Associated Virus Vectors Expressing Herpes Simplex Virus Type 2 Glycoproteins B, and D. J Virol (1997) 71 (10):7960-2. doi: 10.1128/JVI.71.10.7960-7962.1997

66. Bournazos S, Wang TT, Dahan R, Maamary J, Ravetch JV. Signaling by Antibodies: Recent Progress. Annu Rev Immunol (2017) 35:285-311. doi: 10.1146/annurev-immunol-051116-052433

67. Saunders KO. Conceptual Approaches to Modulating Antibody Effector Functions and Circulation Half-Life. Front Immunol (2019) 10:1296. doi: 10.3389/fimmu.2019.01296

68. Tiller KE, Tessier PM. Advances in Antibody Design. Annu Rev BioMed Eng (2015) 17:191-216. doi: 10.1146/annurev-bioeng-071114-040733

69. McHeyzer-Williams LJ, McHeyzer-Williams MG. Antigen-Specific Memory B Cell Development. Annu Rev Immunol (2005) 23:487-513. doi: 10.1146/ annurev.immunol.23.021704.115732

70. Fuchs SP, Martinez-Navio JM, Piatak MJr., Lifson JD, Gao G, Desrosiers RC. Aav-Delivered Antibody Mediates Significant Protective Effects Against SIVmac239 Challenge in the Absence of Neutralizing Activity. PloS Pathog (2015) 11(8):e1005090. doi: 10.1371/journal.ppat.1005090

71. Martinez-Navio JM, Fuchs SP, Pantry SN, Lauer WA, Duggan NN, Keele BF, et al. Adeno-Associated Virus Delivery of Anti-HIV Monoclonal Antibodies can Drive Long-Term Virologic Suppression. Immunity (2019) 50(3):56775.e5. doi: 10.1016/j.immuni.2019.02.005

72. Wu Z, Yang H, Colosi P. Effect of Genome Size on AAV Vector Packaging. Mol Ther (2010) 18(1):80-6. doi: 10.1038/mt.2009.255

73. Julg B, Liu PT, Wagh K, Fischer WM, Abbink P, Mercado NB, et al. Protection Against a Mixed SHIV Challenge by a Broadly Neutralizing Antibody Cocktail. Sci Transl Med (2017) 9(408). doi: 10.1126/scitranslmed.aao4235

74. Shapiro MB, Cheever T, Malherbe DC, Pandey S, Reed J, Yang ES, et al. Single-Dose bNAb Cocktail or Abbreviated ART Post-Exposure Regimens Achieve Tight SHIV Control Without Adaptive Immunity. Nat Commun (2020) 11(1):70. doi: 10.1038/s41467-019-13972-y

75. Fuchs SP, Desrosiers RC. Promise and Problems Associated With the Use of Recombinant AAV for the Delivery of anti-HIV Antibodies. Mol Ther Methods Clin Dev (2016) 3:16068. doi: 10.1038/mtm.2016.68

76. Wang D, Zhang F, Gao G. Crispr-Based Therapeutic Genome Editing: Strategies and In Vivo Delivery by AAV Vectors. Cell (2020) 181(1):136-50. doi: $10.1016 /$ j.cell.2020.03.023

77. Tornabene P, Trapani I. Can Adeno-Associated Viral Vectors Deliver Effectively Large Genes? Hum Gene Ther (2020) 31(1-2):47-56. doi: 10.1089/hum.2019.220

78. Han L, Chen J, Ding K, Zong H, Xie Y, Jiang H, et al. Efficient Generation of Bispecific IgG Antibodies by Split Intein Mediated Protein Trans-Splicing System. Sci Rep (2017) 7(1):8360. doi: 10.1038/s41598-017-08641-3

79. Kou J, Kim H, Pattanayak A, Song M, Lim JE, Taguchi H, et al. Anti-AmyloidBeta Single-Chain Antibody Brain Delivery Via Aav Reduces Amyloid Load But May Increase Cerebral Hemorrhages in an Alzheimer's Disease Mouse Model. J Alzheimers Dis (2011) 27(1):23-38. doi: 10.3233/JAD-2011-110230

80. Wang YJ, Gao CY, Yang M, Liu XH, Sun Y, Pollard A, et al. Intramuscular Delivery of a Single Chain Antibody Gene Prevents Brain Abeta Deposition and Cognitive Impairment in a Mouse Model of Alzheimer's Disease. Brain Behav Immun (2010) 24(8):1281-93. doi: 10.1016/j.bbi.2010.05.010

81. Patel P, Kriz J, Gravel M, Soucy G, Bareil C, Gravel C, et al. Adeno-Associated Virus-Mediated Delivery of a Recombinant Single-Chain Antibody Against Misfolded Superoxide Dismutase for Treatment of Amyotrophic Lateral Sclerosis. Mol Ther (2014) 22(3):498-510. doi: 10.1038/mt.2013.239

82. Wuertzer CA, Sullivan MA, Qiu X, Federoff HJ. CNS Delivery of Vectored Prion-Specific Single-Chain Antibodies Delays Disease Onset. Mol Ther (2008) 16(3):481-6. doi: 10.1038/sj.mt.6300387 
83. Keizer RJ, Huitema AD, Schellens JH, Beijnen JH. Clinical Pharmacokinetics of Therapeutic Monoclonal Antibodies. Clin Pharmacokinet (2010) 49 (8):493-507. doi: 10.2165/11531280-000000000-00000

84. Kessler M, Goldsmith D, Schellekens H. Immunogenicity of Biopharmaceuticals. Nephrol Dial Transplant (2006) 21(Suppl 5):v9-12. doi: $10.1093 / \mathrm{ndt} / \mathrm{gfl} 476$

85. Krishna M, Nadler SG. Immunogenicity to Biotherapeutics - The Role of Anti-drug Immune Complexes. Front Immunol (2016) 7:21. doi: 10.3389/ fimmu.2016.00021

86. Descotes J. Immunotoxicity of Monoclonal Antibodies. MAbs (2009) 1 (2):104-11. doi: 10.4161/mabs.1.2.7909

87. Martinez-Navio JM, Fuchs SP, Pedreno-Lopez S, Rakasz EG, Gao G, Desrosiers RC. Host Anti-antibody Responses Following AdenoAssociated Virus-mediated Delivery of Antibodies Against HIV and SIV in Rhesus Monkeys. Mol Ther (2016) 24(1):76-86. doi: 10.1038/mt.2015.191

88. Welles HC, Jennewein MF, Mason RD, Narpala S, Wang L, Cheng C, et al. Vectored Delivery of anti-SIV Envelope Targeting mAb Via AAV8 Protects Rhesus Macaques From Repeated Limiting Dose Intrarectal Swarm SIVsmE660 Challenge. PloS Pathog (2018) 14(12):e1007395. doi: 10.1371/ journal.ppat.1007395

89. Priddy FH, Lewis DJM, Gelderblom HC, Hassanin H, Streatfield C, LaBranche C, et al. Adeno-Associated Virus Vectored Immunoprophylaxis to Prevent HIV in Healthy Adults: A Phase 1 Randomised Controlled Trial. Lancet HIV (2019) 6(4):e230-e9. doi: 10.1016/S2352-3018(19)30003-7

90. Ben-Horin S, Heap GA, Ahmad T, Kim H, Kwon T, Chowers Y. The Immunogenicity of Biosimilar Infliximab: can We Extrapolate the Data Across Indications? Expert Rev Gastroenterol Hepatol (2015) 9(Suppl 1):2734. doi: 10.1586/17474124.2015.1091307

91. Lewis AD, Chen R, Montefiori DC, Johnson PR, Clark KR. Generation of Neutralizing Activity Against Human Immunodeficiency Virus Type 1 in Serum by Antibody Gene Transfer. J Virol (2002) 76(17):8769-75. doi: 10.1128/JVI.76.17.8769-8775.2002

92. Balazs AB, Chen J, Hong CM, Rao DS, Yang L, Baltimore D. Antibody-Based Protection Against HIV Infection by Vectored Immunoprophylaxis. Nature (2011) 481(7379):81-4. doi: 10.1038/nature10660

93. Johnson PR, Schnepp BC, Zhang J, Connell MJ, Greene SM, Yuste E, et al. Vector-Mediated Gene Transfer Engenders Long-Lived Neutralizing Activity and Protection Against SIV Infection in Monkeys. Nat Med (2009) 15(8):901-6. doi: 10.1038/nm.1967

94. Saunders KO, Wang L, Joyce MG, Yang ZY, Balazs AB, Cheng C, et al. Broadly Neutralizing Human Immunodeficiency Virus Type 1 Antibody Gene Transfer Protects Nonhuman Primates From Mucosal Simian-Human Immunodeficiency Virus Infection. J Virol (2015) 89(16):8334-45. doi: 10.1128/JVI.00908-15

95. Gardner MR, Kattenhorn LM, Kondur HR, von Schaewen M, Dorfman T, Chiang JJ, et al. AAV-Expressed eCD4-Ig Provides Durable Protection From Multiple SHIV Challenges. Nature (2015) 519(7541):87-91. doi: 10.1038/ nature14264

96. Gardner MR, Fellinger CH, Kattenhorn LM, Davis-Gardner ME, Weber JA, Alfant B, et al. AAV-Delivered eCD4-Ig Protects Rhesus Macaques From High-Dose SIVmac239 Challenges. Sci Transl Med (2019) 11(502). doi: 10.1126/scitranslmed.aau5409

97. Balazs AB, Bloom JD, Hong CM, Rao DS, Baltimore D. Broad Protection Against Influenza Infection by Vectored Immunoprophylaxis in Mice. Nat Biotechnol (2013) 31(7):647-52. doi: 10.1038/nbt.2618

98. Limberis MP, Adam VS, Wong G, Gren J, Kobasa D, Ross TM, et al. Intranasal Antibody Gene Transfer in Mice and Ferrets Elicits Broad Protection Against Pandemic Influenza. Sci Transl Med (2013) 5 (187):187ra72. doi: 10.1126/scitranslmed.3006299

99. Limberis MP, Racine T, Kobasa D, Li Y, Gao GF, Kobinger G, et al. Vectored Expression of the Broadly Neutralizing Antibody FI6 in Mouse Airway Provides Partial Protection Against a New Avian Influenza A Virus, H7N9. Clin Vaccine Immunol (2013) 20(12):1836-7. doi: 10.1128/CVI. 00545-13

100. Adam VS, Crosariol M, Kumar S, Ge MQ, Czack SE, Roy S, et al. AdenoAssociated Virus 9-Mediated Airway Expression of Antibody Protects Old and Immunodeficient Mice Against Influenza Virus. Clin Vaccine Immunol (2014) 21(11):1528-33. doi: 10.1128/CVI.00572-14
101. Laursen NS, Friesen RHE, Zhu X, Jongeneelen M, Blokland S, Vermond J, et al. Universal Protection Against Influenza Infection by a Multidomain Antibody to Influenza Hemagglutinin. Science (2018) 362(6414):598-602. doi: $10.1126 /$ science.aaq0620

102. Del Rosario JMM, Smith M, Zaki K, Risley P, Temperton N, Engelhardt OG, et al. Protection From Influenza by Intramuscular Gene Vector Delivery of a Broadly Neutralizing Nanobody Does Not Depend on Antibody Dependent Cellular Cytotoxicity. Front Immunol (2020) 11:627. doi: 10.3389/ fimmu.2020.00627

103. Nistal-Villan E, Rodriguez-Garcia E, Di Scala M, Ferrero-Laborda R, Olague C, Vales A, et al. A RIG-I 2card-Mavs200 Chimeric Protein Reconstitutes IFNBeta Induction and Antiviral Response in Models Deficient in Type I Ifn Response. J Innate Immun (2015) 7(5):466-81. doi: 10.1159/000375262

104. Demminger DE, Walz L, Dietert K, Hoffmann H, Planz O, Gruber AD, et al. Adeno-Associated Virus-Vectored Influenza Vaccine Elicits Neutralizing and Fcgamma Receptor-Activating Antibodies. EMBO Mol Med (2020) 12 (5):e10938. doi: 10.15252/emmm.201910938

105. Du L, Zhao G, Lin Y, Sui H, Chan C, Ma S, et al. Intranasal Vaccination of Recombinant Adeno-Associated Virus Encoding Receptor-Binding Domain of Severe Acute Respiratory Syndrome Coronavirus (SARS-CoV) Spike Protein Induces Strong Mucosal Immune Responses and Provides LongTerm Protection Against SARS-CoV Infection. J Immunol (2008) 180 (2):948-56. doi: 10.4049/jimmunol.180.2.948

106. Logan GJ, Wang L, Zheng M, Cunningham SC, Coppel RL, Alexander IE. AAV Vectors Encoding Malarial Antigens Stimulate Antigen-Specific Immunity But do Not Protect From Parasite Infection. Vaccine (2007) 25 (6):1014-22. doi: 10.1016/j.vaccine.2006.09.072

107. Deal C, Balazs AB, Espinosa DA, Zavala F, Baltimore D, Ketner G. Vectored Antibody Gene Delivery Protects Against Plasmodium Falciparum Sporozoite Challenge in Mice. Proc Natl Acad Sci USA (2014) 111 (34):12528-32. doi: 10.1073/pnas.1407362111

108. Yusuf Y, Yoshii T, Iyori M, Mizukami H, Fukumoto S, Yamamoto DS, et al. A Viral-Vectored Multi-Stage Malaria Vaccine Regimen With Protective and Transmission-Blocking Efficacies. Front Immunol (2019) 10:2412. doi: 10.3389/fimmu.2019.02412

109. Yusuf Y, Yoshii T, Iyori M, Yoshida K, Mizukami H, Fukumoto S, et al. AdenoAssociated Virus as an Effective Malaria Booster Vaccine Following Adenovirus Priming. Front Immunol (2019) 10:730. doi: 10.3389/fimmu. 2019.00730

110. Hentzschel F, Hammerschmidt-Kamper C, Borner K, Heiss K, Knapp B, Sattler JM, et al. AAV8-Mediated In Vivo Overexpression of miR-155 Enhances the Protective Capacity of Genetically Attenuated Malarial Parasites. Mol Ther (2014) 22(12):2130-41. doi: 10.1038/mt.2014.172

111. Mekonnen ZA, Grubor-Bauk B, English K, Leung P, Masavuli MG, Shrestha AC, et al. Single-Dose Vaccination With a Hepatotropic Adeno-Associated Virus Efficiently Localizes T Cell Immunity in the Liver With the Potential to Confer Rapid Protection Against Hepatitis C Virus. J Virol (2019) 93(19). doi: 10.1128/JVI.00202-19

112. Zhu F, Chen T, Zhang Y, Sun H, Cao H, Lu J, et al. A Novel AdenoAssociated Virus-Based Genetic Vaccine Encoding the Hepatitis C Virus NS3/4 Protein Exhibits Immunogenic Properties in Mice Superior to Those of an NS3-Protein-Based Vaccine. PloS One (2015) 10(11):e0142349. doi: 10.1371/journal.pone.0142349

113. Zhu F, Wang Y, Xu Z, Qu H, Zhang H, Niu L, et al. Novel Adenoassociated Virusbased Genetic Vaccines Encoding Hepatitis C Virus E2 Glycoprotein Elicit Humoral Immune Responses in Mice. Mol Med Rep (2019) 19 (2):1016-23. doi: 10.3892/mmr.2018.9739

114. Zhou L, Zhu T, Ye X, Yang L, Wang B, Liang X, et al. Long-Term Protection Against Human Papillomavirus e7-positive Tumor by a Single Vaccination of Adeno-Associated Virus Vectors Encoding a Fusion Protein of Inactivated E7 of Human Papillomavirus 16/18 and Heat Shock Protein 70. Hum Gene Ther (2010) 21(1):109-19. doi: 10.1089/hum.2009.139

115. Nieto K, Stahl-Hennig C, Leuchs B, Muller M, Gissmann L, Kleinschmidt JA. Intranasal Vaccination With AAV5 and 9 Vectors Against Human Papillomavirus Type 16 in Rhesus Macaques. Hum Gene Ther (2012) 23 (7):733-41. doi: 10.1089/hum.2011.202

116. Limberis MP, Tretiakova A, Nambiar K, Wong G, Racine T, Crosariol M, et al. Adeno-Associated Virus Serotype 9-Expressed ZMapp in Mice Confers 
Protection Against Systemic and Airway-Acquired Ebola Virus Infection. J Infect Dis (2016) 214(12):1975-9. doi: 10.1093/infdis/jiw460

117. Robert MA, Nassoury N, Chahal PS, Venne MH, Racine T, Qiu X, et al. Gene Transfer of ZMapp Antibodies Mediated by Recombinant Adeno-Associated Virus Protects Against Ebola Infections. Hum Gene Ther (2018) 29(4):45266. doi: 10.1089/hum.2017.101

118. van Lieshout LP, Soule G, Sorensen D, Frost KL, He S, Tierney K, et al. Intramuscular Adeno-Associated Virus-Mediated Expression of Monoclonal Antibodies Provides 100\% Protection Against Ebola Virus Infection in Mice. J Infect Dis (2018) 217(6):916-25. doi: 10.1093/infdis/jix644

119. Magnani DM, Ricciardi MJ, Bailey VK, Gutman MJ, Pedreno-Lopez N, Silveira CGT, et al. Dengue Virus Evades AAV-Mediated Neutralizing Antibody Prophylaxis in Rhesus Monkeys. Mol Ther (2017) 25(10):232331. doi: 10.1016/j.ymthe.2017.06.020

120. Li X, Cao H, Wang Q, Di B, Wang M, Lu J, et al. Novel AAV-based Genetic Vaccines Encoding Truncated Dengue Virus Envelope Proteins Elicit Humoral Immune Responses in Mice. Microbes Infect (2012) 14(11):10007. doi: 10.1016/j.micinf.2012.05.002

121. Slon-Campos JL, Poggianella M, Zentilin L, Burrone OR. Use of Adenoassociated Viral Vectors to Improve Delivery of a DNA Vaccine Against Dengue Virus. J Gen Virol (2020) 101(1):73-8. doi: 10.1099/jgv.0.001351

122. Zuber C, Mitteregger G, Schuhmann N, Rey C, Knackmuss S, Rupprecht W, et al. Delivery of Single-Chain Antibodies (scFvs) Directed Against the 37/67 $\mathrm{kDa}$ Laminin Receptor Into Mice Via Recombinant Adeno-Associated Viral Vectors for Prion Disease Gene Therapy. J Gen Virol (2008) 89(Pt 8):205561. doi: 10.1099/vir.0.83670-0

123. Moda F, Vimercati C, Campagnani I, Ruggerone M, Giaccone G, Morbin M, et al. Brain Delivery of AAV9 Expressing an anti-PrP Monovalent Antibody Delays Prion Disease in Mice. Prion (2012) 6(4):383-90. doi: 10.4161/ pri.20197

124. Liu C, Li J, Yao Q, Gao Z, Cheng Y, Zhou M, et al. AAV-Expressed G Protein Induces Robust Humoral and Cellular Immune Response and Provides Durable Protection From Rabies Virus Challenges in Mice. Vet Microbiol (2020) 242:108578. doi: 10.1016/j.vetmic.2020.108578

125. Turiak L, Shao C, Meng L, Khatri K, Leymarie N, Wang Q, et al. Workflow for Combined Proteomics and Glycomics Profiling From Histological Tissues. Anal Chem (2014) 86(19):9670-8. doi: 10.1021/ac5022216

126. Johnson MJ, Laoharawee K, Lahr WS, Webber BR, Moriarity BS. Engineering of Primary Human B Cells With CRISPR/Cas9 Targeted Nuclease. Sci Rep (2018) 8(1):12144. doi: 10.1038/s41598-018-30358-0

127. Ling C, Bhukhai K, Yin Z, Tan M, Yoder MC, Leboulch P, et al. High-Efficiency Transduction of Primary Human Hematopoietic Stem/Progenitor Cells by AAV6 Vectors: Strategies for Overcoming Donor-Variation and Implications in Genome Editing. Sci Rep (2016) 6:35495. doi: 10.1038/srep35495

128. Nelson AL, Dhimolea E, Reichert JM. Development Trends for Human Monoclonal Antibody Therapeutics. Nat Rev Drug Discovery (2010) 9 (10):767-74. doi: 10.1038/nrd3229

129. Pfizer Presents Initial Clinical Data On Phase 16 Gene Therapy Study for Duchenne Muscular Dystrophy (Dmd) (2019). Available at: https://www. pfizer.com/news/press-release/press-release-detail/pfizer_presents_initial_ clinical_data_on_phase_1b_gene_therapy_study_for_duchenne_muscular_ dystrophy_dmd.

130. Solid Biosciences Provides SGT-001 Program (2019). Available at: https:// www.solidbio.com/about/media/press-releases/solid-biosciences-providessgt-001-program-update.

131. Keeler GD, Markusic DM, Hoffman BE. Liver Induced Transgene Tolerance With AAV Vectors. Cell Immunol (2019) 342:103728. doi: 10.1016/ j.cellimm.2017.12.002

132. Horst AK, Neumann K, Diehl L, Tiegs G. Modulation of Liver Tolerance by Conventional and Nonconventional Antigen-Presenting Cells and Regulatory Immune Cells. Cell Mol Immunol (2016) 13(3):277-92. doi: 10.1038/cmi.2015.112

133. Fang J, Yi S, Simmons A, Tu GH, Nguyen M, Harding TC, et al. An Antibody Delivery System for Regulated Expression of Therapeutic Levels of Monoclonal Antibodies In Vivo. Mol Ther (2007) 15(6):1153-9. doi: 10.1038/sj.mt.6300142

134. Rivera VM, Gao GP, Grant RL, Schnell MA, Zoltick PW, Rozamus LW, et al. Long-Term Pharmacologically Regulated Expression of Erythropoietin in
Primates Following AAV-mediated Gene Transfer. Blood (2005) 105 (4):1424-30. doi: 10.1182/blood-2004-06-2501

135. Nguyen M, Huan-Tu G, Gonzalez-Edick M, Rivera VM, Clackson T, Jooss KU, et al. Rapamycin-Regulated Control of Antiangiogenic Tumor Therapy Following rAAV-mediated Gene Transfer. Mol Ther (2007) 15(5):912-20. doi: $10.1038 / \mathrm{mt}$. sj. 6300079

136. Li A, Lee CM, Hurley AE, Jarrett KE, De Giorgi M, Lu W, et al. A SelfDeleting Aav-Crispr System for In Vivo Genome Editing. Mol Ther Methods Clin Dev (2019) 12:111-22. doi: 10.1016/j.omtm.2018.11.009

137. Falese L, Sandza K, Yates B, Triffault S, Gangar S, Long B, et al. Strategy to Detect Pre-Existing Immunity to AAV Gene Therapy. Gene Ther (2017) 24 (12):768-78. doi: 10.1038/gt.2017.95

138. Calcedo R, Morizono H, Wang L, McCarter R, He J, Jones D, et al. Adeno-Associated Virus Antibody Profiles in Newborns, Children, and Adolescents. Clin Vaccine Immunol (2011) 18(9):1586-8. doi: 10.1128/ CVI.05107-11

139. Boutin S, Monteilhet V, Veron P, Leborgne C, Benveniste O, Montus MF, et al. Prevalence of Serum IgG and Neutralizing Factors Against AdenoAssociated Virus (AAV) Types 1, 2, 5, 6, 8, and 9 in the Healthy Population: Implications for Gene Therapy Using AAV Vectors. Hum Gene Ther (2010) 21(6):704-12. doi: 10.1089/hum.2009.182

140. Jiang H, Couto LB, Patarroyo-White S, Liu T, Nagy D, Vargas JA, et al. Effects of Transient Immunosuppression on Adenoassociated, VirusMediated, Liver-Directed Gene Transfer in Rhesus Macaques and Implications for Human Gene Therapy. Blood (2006) 108(10):3321-8. doi: 10.1182/blood-2006-04-017913

141. Manno CS, Pierce GF, Arruda VR, Glader B, Ragni M, Rasko JJ, et al. Successful Transduction of Liver in Hemophilia by AAV-Factor IX and Limitations Imposed by the Host Immune Response. Nat Med (2006) 12 (3):342-7. doi: 10.1038/nm1358

142. Scallan CD, Jiang H, Liu T, Patarroyo-White S, Sommer JM, Zhou S, et al. Human Immunoglobulin Inhibits Liver Transduction by AAV Vectors At Low AAV2 Neutralizing Titers in SCID Mice. Blood (2006) 107(5):1810-7. doi: 10.1182/blood-2005-08-3229

143. Mingozzi F, Maus MV, Hui DJ, Sabatino DE, Murphy SL, Rasko JE, et al. Cd8(+) T-cell Responses to Adeno-Associated Virus Capsid in Humans. Nat Med (2007) 13(4):419-22. doi: 10.1038/nm1549

144. Mingozzi F, High KA. Immune Responses to AAV in Clinical Trials. Curr Gene Ther (2011) 11(4):321-30. doi: 10.2174/156652311796150354

145. Mingozzi F, Meulenberg JJ, Hui DJ, Basner-Tschakarjan E, Hasbrouck NC, Edmonson SA, et al. Aav-1-mediated Gene Transfer to Skeletal Muscle in Humans Results in Dose-Dependent Activation of Capsid-Specific T Cells. Blood (2009) 114(10):2077-86. doi: 10.1182/blood-2008-07-167510

146. Mueller C, Chulay JD, Trapnell BC, Humphries M, Carey B, Sandhaus RA, et al. Human Treg Responses Allow Sustained Recombinant AdenoAssociated Virus-Mediated Transgene Expression. J Clin Invest (2013) 123 (12):5310-8. doi: 10.1172/JCI70314

147. Elmore ZC, Oh DK, Simon KE, Fanous MM, Asokan A. Rescuing AAV Gene Transfer From Neutralizing Antibodies With an IgG-degrading Enzyme. JCI Insight (2020) 5(19). doi: 10.1172/jci.insight.139881

148. Leborgne C, Barbon E, Alexander JM, Hanby H, Delignat S, Cohen DM, et al. IgG-cleaving Endopeptidase Enables In Vivo Gene Therapy in the Presence of anti-AAV Neutralizing Antibodies. Nat Med (2020) 26(7):1096-101. doi: 10.1038/s41591-020-0911-7

149. Meliani A, Boisgerault F, Hardet R, Marmier S, Collaud F, Ronzitti G, et al. Antigen-Selective Modulation of AAV Immunogenicity With Tolerogenic Rapamycin Nanoparticles Enables Successful Vector Re-Administration. Nat Commun (2018) 9(1):4098. doi: 10.1038/s41467-018-06621-3

150. Barnes C, Scheideler O, Schaffer D. Engineering the AAV Capsid to Evade Immune Responses. Curr Opin Biotechnol (2019) 60:99-103. doi: 10.1016/ j.copbio.2019.01.002

151. Louis Jeune V, Joergensen JA, Hajjar RJ, Weber T. Pre-Existing Anti-AdenoAssociated Virus Antibodies as a Challenge in AAV Gene Therapy. Hum Gene Ther Methods (2013) 24(2):59-67. doi: 10.1089/hgtb.2012.243

152. Dalkara D, Byrne LC, Klimczak RR, Visel M, Yin L, Merigan WH, et al. In Vivo-Directed Evolution of a New Adeno-Associated Virus for Therapeutic Outer Retinal Gene Delivery From the Vitreous. Sci Transl Med (2013) 5 (189):189ra76. doi: 10.1126/scitranslmed.3005708 
153. Tse LV, Klinc KA, Madigan VJ, Castellanos Rivera RM, Wells LF, Havlik LP, et al. Structure-Guided Evolution of Antigenically Distinct AdenoAssociated Virus Variants for Immune Evasion. Proc Natl Acad Sci USA (2017) 114(24):E4812-21. doi: 10.1073/pnas.1704766114

154. Wobus CE, Hugle-Dorr B, Girod A, Petersen G, Hallek M, Kleinschmidt JA. Monoclonal Antibodies Against the Adeno-Associated Virus Type 2 (AAV2) Capsid: Epitope Mapping and Identification of Capsid Domains Involved in AAV-2-cell Interaction and Neutralization of AAV-2 Infection. J Virol (2000) 74(19):9281-93. doi: 10.1128/JVI.74.19.9281-9293.2000

155. Li C, Diprimio N, Bowles DE, Hirsch ML, Monahan PE, Asokan A, et al. Single Amino Acid Modification of Adeno-Associated Virus Capsid Changes Transduction and Humoral Immune Profiles. J Virol (2012) 86(15):7752-9. doi: 10.1128/JVI.00675-12

156. Maheshri N, Koerber JT, Kaspar BK, Schaffer DV. Directed Evolution of Adeno-Associated Virus Yields Enhanced Gene Delivery Vectors. Nat Biotechnol (2006) 24(2):198-204. doi: 10.1038/nbt1182

157. Grimm D, Lee JS, Wang L, Desai T, Akache B, Storm TA, et al. In Vitro and In Vivo Gene Therapy Vector Evolution Via Multispecies Interbreeding and Retargeting of Adeno-Associated Viruses. J Virol (2008) 82(12):5887-911. doi: 10.1128/JVI.00254-08

158. Paulk NK, Pekrun K, Zhu E, Nygaard S, Li B, Xu J, et al. Bioengineered AAV Capsids With Combined High Human Liver Transduction in Vivo and Unique Humoral Seroreactivity. Mol Ther (2018) 26(1):289-303. doi: 10.1016/j.ymthe.2017.09.021

159. Monteilhet V, Saheb S, Boutin S, Leborgne C, Veron P, Montus MF, et al. A 10 Patient Case Report on the Impact of Plasmapheresis Upon Neutralizing Factors Against Adeno-Associated Virus (AAV) Types 1, 2, 6, and 8. Mol Ther (2011) 19(11):2084-91. doi: 10.1038/mt.2011.108

160. Chicoine LG, Montgomery CL, Bremer WG, Shontz KM, Griffin DA, Heller $\mathrm{KN}$, et al. Plasmapheresis Eliminates the Negative Impact of AAV Antibodies on Microdystrophin Gene Expression Following Vascular Delivery. Mol Ther (2014) 22(2):338-47. doi: 10.1038/mt.2013.244

161. Bertin B, Veron P, Leborgne C, Deschamps JY, Moullec S, Fromes Y, et al. Capsid-Specific Removal of Circulating Antibodies to Adeno-Associated Virus Vectors. Sci Rep (2020) 10(1):864. doi: 10.1038/s41598-020-57893-Z

162. Vandamme C, Adjali O, Mingozzi F. Unraveling the Complex Story of Immune Responses to AAV Vectors Trial After Trial. Hum Gene Ther (2017) 28(11):1061-74. doi: 10.1089/hum.2017.150

163. Mingozzi F, Anguela XM, Pavani G, Chen Y, Davidson RJ, Hui DJ, et al. Overcoming Preexisting Humoral Immunity to AAV Using Capsid Decoys. Sci Transl Med (2013) 5(194):194ra92. doi: 10.1126/scitranslmed.3005795

164. Ekeruche-Makinde J, Miles JJ, van den Berg HA, Skowera A, Cole DK, Dolton G, et al. Peptide Length Determines the Outcome of TCR/peptideMHCI Engagement. Blood (2013) 121(7):1112-23. doi: 10.1182/blood-201206-437202

165. Flotte TR. Revisiting the "New" Inflammatory Toxicities of Adeno-Associated Virus Vectors. Hum Gene Ther (2020) 31(7-8):398-9. doi: 10.1089/ hum.2020.29117.trf

166. Hordeaux J, Hinderer C, Goode T, Katz N, Buza EL, Bell P, et al. Toxicology Study of Intra-Cisterna Magna Adeno-Associated Virus 9 Expressing Human Alpha-L-Iduronidase in Rhesus Macaques. Mol Ther Methods Clin $\operatorname{Dev}$ (2018) 10:79-88. doi: 10.1016/j.omtm.2018.06.003

167. Hordeaux J, Hinderer C, Goode T, Buza EL, Bell P, Calcedo R, et al. Toxicology Study of Intra-Cisterna Magna Adeno-Associated Virus 9 Expressing Iduronate-2-Sulfatase in Rhesus Macaques. Mol Ther Methods Clin Dev (2018) 10:68-78. doi: 10.1016/j.omtm.2018.06.004

168. Hinderer C, Katz N, Buza EL, Dyer C, Goode T, Bell P, et al. Severe Toxicity in Nonhuman Primates and Piglets Following High-Dose Intravenous Administration of an Adeno-Associated Virus Vector Expressing Human Smn. Hum Gene Ther (2018) 29(3):285-98. doi: 10.1089/hum.2018.015

169. Perez BA, Shutterly A, Chan YK, Byrne BJ, Corti M. Management of Neuroinflammatory Responses to AAV-Mediated Gene Therapies for Neurodegenerative Diseases. Brain Sci (2020) 10(2). doi: 10.3390/ brainsci10020119

170. Mendell JR, Al-Zaidy S, Shell R, Arnold WD, Rodino-Klapac LR, Prior TW, et al. Single-Dose Gene-Replacement Therapy for Spinal Muscular Atrophy. N Engl J Med (2017) 377(18):1713-22. doi: 10.1056/NEJMoa1706198
171. Audentes Announces Positive Interim Data From First Dose Cohort of ASPIRO, a Phase 1/2 Clinical Trial of AT132 in Patients With X-Linked Myotubular Myopathy. Available at: https://www.prnewswire.com/newsreleases/audentes-announces-positive-interim-data-from-first-dose-cohortof-aspiro-a-phase-12-clinical-trial-of-at132-in-patients-with-x-linkedmyotubular-myopathy-300577455.html\#: :text=All\%20Products-,Audentes $\% 20$ Announces\%20Positive\%20Interim\%20Data\%20from\%20First\% 20Dose $\% 20$ Cohort $\% 20$ of,With\%20X\%2DLinked\%20Myotubular\% 20Myopathy\&text=Audentes\%20Therapeutics $\% 2 \mathrm{C} \% 20 \mathrm{Inc}$. \&text $=\% 22 \mathrm{The}$ $\% 20$ early $\% 20$ AT $132 \% 20$ efficacy $\% 20$ data,our $\% 20$ expectations $\% 2$ C $\% 22 \%$ 20stated\%20Dr.

172. Hale C. Solid Bio Sees Yet Another Clinical Hold for its DMD Gene Therapy. Fierce Biotech (2019) November 12, 2019. Available at: https://www. fiercebiotech.com/biotech/solid-bio-sees-yet-another-clinical-hold-for-itsdmd-gene-therapy.

173. Pfizer's New Phase 1b Results of Gene Therapy In Ambulatory Boys With Duchenne Muscular Dystrophy (Dmd) Support Advancement Into Pivotal Phase 3 Study. Available at: https://investors.pfizer.com/investor-news/ press-release-details/2020/Pfizers-New-Phase-1b-Results-of-Gene-Therapyin-Ambulatory-Boys-with-Duchenne-Muscular-Dystrophy-DMD-SupportAdvancement-into-Pivotal-Phase-3-Study/default.aspx.

174. Rabinowitz J, Chan YK, Samulski RJ. Adeno-Associated Virus (AAV) Versus Immune Response. Viruses (2019) 11(2). doi: 10.3390/v11020102

175. Zhu J, Huang X, Yang Y. The TLR9-MyD88 Pathway is Critical for Adaptive Immune Responses to Adeno-Associated Virus Gene Therapy Vectors in Mice. J Clin Invest (2009) 119(8):2388-98. doi: 10.1172/JCI37607

176. Faust SM, Bell P, Cutler BJ, Ashley SN, Zhu Y, Rabinowitz JE, et al. CpGdepleted Adeno-Associated Virus Vectors Evade Immune Detection. J Clin Invest (2013) 123(7):2994-3001. doi: 10.1172/JCI68205

177. Ashley SN, Somanathan S, Giles AR, Wilson JM. TLR9 Signaling Mediates Adaptive Immunity Following Systemic AAV Gene Therapy. Cell Immunol (2019) 346:103997. doi: 10.1016/j.cellimm.2019.103997

178. Rogers GL, Shirley JL, Zolotukhin I, Kumar SRP, Sherman A, Perrin GQ, et al. Plasmacytoid and Conventional Dendritic Cells Cooperate in Crosspriming AAV Capsid-Specific CD8(+) T Cells. Blood (2017) 129 (24):3184-95. doi: 10.1182/blood-2016-11-751040

179. Butterfield JSS, Biswas M, Shirley JL, Kumar SRP, Sherman A, Terhorst C, et al. Tlr9-Activating CpG-B ODN But Not Tlr7 Agonists Triggers Antibody Formation to Factor IX in Muscle Gene Transfer. Hum Gene Ther Methods (2019) 30(3):81-92. doi: 10.1089/hgtb.2019.013

180. Martino AT, Suzuki M, Markusic DM, Zolotukhin I, Ryals RC, Moghimi B, et al. The Genome of Self-Complementary Adeno-Associated Viral Vectors Increases Toll-like Receptor 9-Dependent Innate Immune Responses in the Liver. Blood (2011) 117(24):6459-68. doi: 10.1182/blood-2010-10-314518

181. Hosel M, Broxtermann M, Janicki H, Esser K, Arzberger S, Hartmann P, et al. Toll-Like Receptor 2-Mediated Innate Immune Response in Human Nonparenchymal Liver Cells Toward Adeno-Associated Viral Vectors. Hepatology (2012) 55(1):287-97. doi: 10.1002/hep.24625

182. Sudres M, Cire S, Vasseur V, Brault L, Da Rocha S, Boisgerault F, et al. MyD88 Signaling in B Cells Regulates the Production of Th1-dependent Antibodies to AAV. Mol Ther (2012) 20(8):1571-81. doi: 10.1038/ $\mathrm{mt} .2012 .101$

183. Chan YK, Wang SK, Chu CJ, Copland DA, Letizia AJ, Costa Verdera H, et al. Engineering Adeno-Associated Viral Vectors to Evade Innate Immune and Inflammatory Responses. Sci Transl Med (2021) 13(580). doi: 10.1126/ scitranslmed.abd 3438

184. Xiao Y, Muhuri M, Li S, Qin W, Xu G, Luo L, et al. Circumventing Cellular Immunity by miR142-mediated Regulation Sufficiently Supports RaavDelivered OVA Expression Without Activating Humoral Immunity. JCI Insight (2019) 5. doi: 10.1172/jci.insight.99052

185. Boisgerault F, Gross DA, Ferrand M, Poupiot J, Darocha S, Richard I, et al. Prolonged Gene Expression in Muscle is Achieved Without Active Immune Tolerance Using microrRNA 142.3p-regulated rAAV Gene Transfer. Hum Gene Ther (2013) 24(4):393-405. doi: 10.1089/hum.2012.208

186. Zabaleta N, Dai W, Bhatt U, Chichester JA, Estelien R, Sanmiguel J, et al. Immunogenicity of an AAV-based, Room-Temperature Stable, Single Dose COVID-19 Vaccine in Mice and non-Human Primates. bioRxiv (2021). doi: $10.1101 / 2021.01 .05 .422952$ 
187. Wu T, Topfer K, Lin SW, Li H, Bian A, Zhou XY, et al. Self-Complementary AAVs Induce More Potent Transgene Product-Specific Immune Responses Compared to a Single-Stranded Genome. Mol Ther (2012) 20(3):572-9. doi: 10.1038/mt.2011.280

188. Paulk N. Genetic Engineering \& Biotechnology News. (2020) 40(9):14-6. doi: $10.1089 /$ gen.40.09.04

189. Rumachik NG, Malaker SA, Poweleit N, Maynard LH, Adams CM, Leib RD, et al. Methods Matter: Standard Production Platforms for Recombinant Aav Produce Chemically and Functionally Distinct Vectors. Mol Ther Methods Clin Dev (2020) 18:98-118. doi: 10.1016/j.omtm.2020.05.018

190. Ayuso E, Mingozzi F, Montane J, Leon X, Anguela XM, Haurigot V, et al. High AAV Vector Purity Results in Serotype- and Tissue-Independent Enhancement of Transduction Efficiency. Gene Ther (2010) 17(4):503-10. doi: $10.1038 /$ gt.2009.157

191. WHO. Hiv/Aids 2020. Available at: https://www.who.int/news-room/factsheets/detail/hiv-aids.

192. Freed EO. HIV-1 Assembly, Release and Maturation. Nat Rev Microbiol (2015) 13(8):484-96. doi: 10.1038/nrmicro3490

193. Chan DC, Fass D, Berger JM, Kim PS. Core Structure of gp41 From the HIV Envelope Glycoprotein. Cell (1997) 89(2):263-73. doi: 10.1016/S0092-8674 (00)80205-6

194. Smith JA, Daniel R. Following the Path of the Virus: The Exploitation of Host DNA Repair Mechanisms by Retroviruses. ACS Chem Biol (2006) 1 (4):217-26. doi: 10.1021/cb600131q

195. Andrews SM, Rowland-Jones S. Recent Advances in Understanding HIV Evolution. F1000Res (2017) 6:597. doi: 10.12688/f1000research.10876.1

196. Cohen YZ, Caskey M. Broadly Neutralizing Antibodies for Treatment and Prevention of HIV-1 Infection. Curr Opin HIV AIDS (2018) 13(4):366-73. doi: $10.1097 / \mathrm{COH} .0000000000000475$

197. Klein JS, Bjorkman PJ. Few and Far Between: How HIV may be Evading Antibody Avidity. PloS Pathog (2010) 6(5):e1000908. doi: 10.1371/ journal.ppat.1000908

198. Crotty S. Follicular Helper CD4 T Cells (TFH). Annu Rev Immunol (2011) 29:621-63. doi: 10.1146/annurev-immunol-031210-101400

199. Shingai M, Donau OK, Plishka RJ, Buckler-White A, Mascola JR, Nabel GJ, et al. Passive Transfer of Modest Titers of Potent and Broadly Neutralizing anti-HIV Monoclonal Antibodies Block SHIV Infection in Macaques. J Exp Med (2014) 211(10):2061-74. doi: 10.1084/jem.20132494

200. Bar-On Y, Gruell H, Schoofs T, Pai JA, Nogueira L, Butler AL, et al. Safety and Antiviral Activity of Combination HIV-1 Broadly Neutralizing Antibodies in Viremic Individuals. Nat Med (2018) 24(11):1701-7. doi: 10.1038/s41591-018-0186-4

201. Mendoza P, Gruell H, Nogueira L, Pai JA, Butler AL, Millard K, et al. Combination Therapy With anti-HIV-1 Antibodies Maintains Viral Suppression. Nature (2018) 561(7724):479-84. doi: 10.1038/s41586-018-0531-2

202. Caskey M, Klein F, Nussenzweig MC. Broadly Neutralizing anti-HIV-1 Monoclonal Antibodies in the Clinic. Nat Med (2019) 25(4):547-53. doi: 10.1038/s41591-019-0412-8

203. Prevention CfDCa. Past Seasons Estimated Influenza Disease Burden. Available at: https://www.cdc.gov/flu/about/burden/past-seasons.html.

204. Oliveira EC, Lee B, Colice GL. Influenza in the Intensive Care Unit. J Intensive Care Med (2003) 18(2):80-91. doi: 10.1177/0885066602250368

205. Osterholm MT, Kelley NS, Sommer A, Belongia EA. Efficacy and Effectiveness of Influenza Vaccines: A Systematic Review and MetaAnalysis. Lancet Infect Dis (2012) 12(1):36-44. doi: 10.1016/S1473-3099 (11)70295-X

206. Beyer WE, McElhaney J, Smith DJ, Monto AS, Nguyen-Van-Tam JS, Osterhaus AD. Cochrane Re-Arranged: Support for Policies to Vaccinate Elderly People Against Influenza. Vaccine (2013) 31(50):6030-3. doi: 10.1016/j.vaccine.2013.09.063

207. Chen H, Smith GJ, Zhang SY, Qin K, Wang J, Li KS, et al. Avian Flu: H5N1 Virus Outbreak in Migratory Waterfowl. Nature (2005) 436(7048):191-2. doi: $10.1038 /$ nature 03974

208. Krammer F, Smith GJD, Fouchier RAM, Peiris M, Kedzierska K, Doherty PC, et al. Influenza. Nat Rev Dis Primers (2018) 4(1):3. doi: 10.1038/s41572018-0002-y

209. Boni MF. Vaccination and Antigenic Drift in Influenza. Vaccine (2008) 26 (Suppl 3):C8-14. doi: 10.1016/j.vaccine.2008.04.011
210. Caton AJ, Brownlee GG, Yewdell JW, Gerhard W. The Antigenic Structure of the Influenza Virus A/PR/8/34 Hemagglutinin (H1 Subtype). Cell (1982) 31(2 Pt 1):417-27. doi: 10.1016/0092-8674(82)90135-0

211. Corti D, Voss J, Gamblin SJ, Codoni G, Macagno A, Jarrossay D, et al. A Neutralizing Antibody Selected From Plasma Cells That Binds to Group 1 and Group 2 Influenza A Hemagglutinins. Science (2011) 333(6044):850-6. doi: $10.1126 /$ science. 1205669

212. Dreyfus C, Laursen NS, Kwaks T, Zuijdgeest D, Khayat R, Ekiert DC, et al. Highly Conserved Protective Epitopes on Influenza B Viruses. Science (2012) 337(6100):1343-8. doi: 10.1126/science. 1222908

213. Ekiert DC, Friesen RH, Bhabha G, Kwaks T, Jongeneelen M, Yu W, et al. A Highly Conserved Neutralizing Epitope on Group 2 Influenza A Viruses. Science (2011) 333(6044):843-50. doi: 10.1126/science.1204839

214. Ekiert DC, Bhabha G, Elsliger MA, Friesen RH, Jongeneelen M, Throsby M, et al. Antibody Recognition of a Highly Conserved Influenza Virus Epitope. Science (2009) 324(5924):246-51. doi: 10.1126/science.1171491

215. Brandenburg B, Koudstaal W, Goudsmit J, Klaren V, Tang C, Bujny MV, et al. Mechanisms of Hemagglutinin Targeted Influenza Virus Neutralization. PloS One (2013) 8(12):e80034. doi: 10.1371/journal.pone.0080034

216. YuX, TsibaneT, McGraw PA, House FS, Keefer CJ, Hicar MD, et al. Neutralizing Antibodies Derived From the B Cells of 1918 Influenza Pandemic Survivors. Nature (2008) 455(7212):532-6. doi: 10.1038/nature07231

217. Sui J, Hwang WC, Perez S, Wei G, Aird D, Chen LM, et al. Structural and Functional Bases for Broad-Spectrum Neutralization of Avian and Human Influenza A Viruses. Nat Struct Mol Biol (2009) 16(3):265-73. doi: 10.1038/ nsmb.1566

218. DiLillo DJ, Tan GS, Palese P, Ravetch JV. Broadly Neutralizing Hemagglutinin Stalk-Specific Antibodies Require FcgammaR Interactions for Protection Against Influenza Virus In Vivo. Nat Med (2014) 20(2):143-51. doi: 10.1038/ nm.3443

219. Throsby M, van den Brink E, Jongeneelen M, Poon LL, Alard P, Cornelissen L, et al. Heterosubtypic Neutralizing Monoclonal Antibodies Cross-Protective Against H5N1 and H1N1 Recovered From Human IgM+ Memory B Cells. PloS One (2008) 3(12):e3942. doi: 10.1371/journal.pone.0003942

220. Quinn K, Quirion MR, Lo CY, Misplon JA, Epstein SL, Chiorini JA. Intranasal Administration of Adeno-Associated Virus Type 12 (AAV12) Leads to Transduction of the Nasal Epithelia and can Initiate TransgeneSpecific Immune Response. Mol Ther (2011) 19(11):1990-8. doi: 10.1038/ mt.2011.146

221. Chambers TJ, Hahn CS, Galler R, Rice CM. Flavivirus Genome Organization, Expression, and Replication. Annu Rev Microbiol (1990) 44:649-88. doi: 10.1146/annurev.mi.44.100190.003245

222. Murray NE, Quam MB, Wilder-Smith A. Epidemiology of Dengue: Past, Present and Future Prospects. Clin Epidemiol (2013) 5:299-309. doi: 10.2147/CLEP.S34440

223. Bhatt S, Gething PW, Brady OJ, Messina JP, Farlow AW, Moyes CL, et al. The Global Distribution and Burden of Dengue. Nature (2013) 496 (7446):504-7. doi: 10.1038/nature12060

224. WHO. Dengue and Severe Dengue (2020). Available at: https://www.who.int/ news-room/fact-sheets/detail/dengue-and-severe-dengue2020.

225. Wang TT, Sewatanon J, Memoli MJ, Wrammert J, Bournazos S, Bhaumik SK, et al. Igg Antibodies to Dengue Enhanced for FcgammaRIIIA Binding Determine Disease Severity. Science (2017) 355(6323):395-8. doi: 10.1126/ science.aai8128

226. Shukla R, Ramasamy V, Shanmugam RK, Ahuja R, Khanna N. AntibodyDependent Enhancement: A Challenge for Developing a Safe Dengue Vaccine. Front Cell Infect Microbiol (2020) 10:572681. doi: 10.3389/ fcimb. 2020.572681

227. Muhammad Azami NA, Takasaki T, Kurane I, Moi ML. Non-Human Primate Models of Dengue Virus Infection: A Comparison of Viremia Levels and Antibody Responses During Primary and Secondary Infection Among Old World and New World Monkeys. Pathogens (2020) 9(4). doi: 10.3390/pathogens 9040247

228. Watanabe S, Chan KW, Wang J, Rivino L, Lok SM, Vasudevan SG. Dengue Virus Infection With Highly Neutralizing Levels of Cross-Reactive Antibodies Causes Acute Lethal Small Intestinal Pathology Without a High Level of Viremia in Mice. J Virol (2015) 89(11):5847-61. doi: 10.1128/JVI.00216-15 
229. Katzelnick LC, Gresh L, Halloran ME, Mercado JC, Kuan G, Gordon A, et al. Antibody-Dependent Enhancement of Severe Dengue Disease in Humans. Science (2017) 358(6365):929-32. doi: 10.1126/science.aan6836

230. Salje H, Cummings DAT, Rodriguez-Barraquer I, Katzelnick LC, Lessler J, Klungthong C, et al. Reconstruction of Antibody Dynamics and Infection Histories to Evaluate Dengue Risk. Nature (2018) 557(7707):719-23. doi: 10.1038/s41586-018-0157-4

231. Sridhar S, Luedtke A, Langevin E, Zhu M, Bonaparte M, Machabert T, et al. Effect of Dengue Serostatus on Dengue Vaccine Safety and Efficacy. N Engl J Med (2018) 379(4):327-40. doi: 10.1056/NEJMoa 1800820

232. Ripoll DR, Wallqvist A, Chaudhury S. Molecular Simulations Reveal the Role of Antibody Fine Specificity and Viral Maturation State on AntibodyDependent Enhancement of Infection in Dengue Virus. Front Cell Infect Microbiol (2019) 9:200. doi: 10.3389/fcimb.2019.00200

233. Xu M, Zuest R, Velumani S, Tukijan F, Toh YX, Appanna R, et al. A Potent Neutralizing Antibody With Therapeutic Potential Against All Four Serotypes of Dengue Virus. NPJ Vaccines (2017) 2:2. doi: 10.1038/s41541016-0003-3

234. Beltramello M, Williams KL, Simmons CP, Macagno A, Simonelli L, Quyen NT, et al. The Human Immune Response to Dengue Virus is Dominated by Highly Cross-Reactive Antibodies Endowed With Neutralizing and Enhancing Activity. Cell Host Microbe (2010) 8(3):271-83. doi: 10.1016/ j.chom.2010.08.007

235. Williams KL, Sukupolvi-Petty S, Beltramello M, Johnson S, Sallusto F, Lanzavecchia A, et al. Therapeutic Efficacy of Antibodies Lacking Fcgamma Receptor Binding Against Lethal Dengue Virus Infection is Due to Neutralizing Potency and Blocking of Enhancing Antibodies [Corrected]. PloS Pathog (2013) 9(2):e1003157. doi: 10.1371/journal.ppat.1003157

236. Yang X, Yu Y, Xu J, Shu H, Xia J, Liu H, et al. Clinical Course and Outcomes of Critically Ill Patients With SARS-CoV-2 Pneumonia in Wuhan, China: A Single-Centered, Retrospective, Observational Study. Lancet Respir Med (2020) 8(5):475-81. doi: 10.1016/S2213-2600(20)30079-5

237. Krammer F. Sars-CoV-2 Vaccines in Development. Nature (2020) 586 (7830):516-27. doi: 10.1038/s41586-020-2798-3

238. WHO. Coronavirus Disease (COVID-2019) Situation Reports. Available at: https://www.who.int/emergencies/diseases/novel-coronavirus-2019/ situation-reports 2020.

239. Zhu N, Zhang D, Wang W, Li X, Yang B, Song J, et al. A Novel Coronavirus From Patients With Pneumonia in China, 2019. N Engl J Med (2020) 382 (8):727-33. doi: 10.1056/NEJMoa2001017

240. Wrapp D, Wang N, Corbett KS, Goldsmith JA, Hsieh CL, Abiona O, et al. Cryo-EM Structure of the 2019-Ncov Spike in the Prefusion Conformation. Science (2020) 367(6483):1260-3. doi: 10.1126/science.abb2507

241. Liu L, Wei Q, Lin Q, Fang J, Wang H, Kwok H, et al. Anti-Spike IgG Causes Severe Acute Lung Injury by Skewing Macrophage Responses During Acute SARS-CoV Infection. JCI Insight (2019) 4(4). doi: 10.1172/jci.insight.123158

242. Wang Q, Zhang L, Kuwahara K, Li L, Liu Z, Li T, et al. Immunodominant SARS Coronavirus Epitopes in Humans Elicited Both Enhancing and Neutralizing Effects on Infection in Non-human Primates. ACS Infect Dis (2016) 2(5):361-76. doi: 10.1021/acsinfecdis.6b00006

243. Qin E, Shi H, Tang L, Wang C, Chang G, Ding Z, et al. Immunogenicity and Protective Efficacy in Monkeys of Purified Inactivated Vero-cell SARS Vaccine. Vaccine (2006) 24(7):1028-34. doi: 10.1016/j.vaccine.2005.06.038

244. Luo F, Liao FL, Wang H, Tang HB, Yang ZQ, Hou W. Evaluation of Antibody-Dependent Enhancement of SARS-CoV Infection in Rhesus Macaques Immunized With an Inactivated Sars-CoV Vaccine. Virol Sin (2018) 33(2):201-4. doi: 10.1007/s12250-018-0009-2

245. Xie X, Zou J, Fontes-Garfias CR, Xia H, Swanson KA, Cutler M, et al. Neutralization of N501Y Mutant SARS-CoV-2 by BNT162b2 VaccineElicited Sera. bioRxiv (2021) 2021:01.07.425740. doi: 10.1101/2021.01.07.425740

246. Sahin U, Muik A, Vogler I, Derhovanessian E, Kranz LM, Vormehr M, et al. BNT162b2 Induces SARS-CoV-2-neutralising Antibodies and T Cells in Humans. medRxiv (2020) 2020:12.09.20245175. doi: 10.1101/2020.12.09.20245175

247. Widge AT, Rouphael NG, Jackson LA, Anderson EJ, Roberts PC, Makhene M, et al. Durability of Responses After SARS-CoV-2 mRNA-1273 Vaccination. N Engl J Med (2021) 384(1):80-2. doi: 10.1056/NEJMc2032195

248. Massachusetts Eye and Ear and Massachusetts General Hospital Advancing Novel Experimental Gene-based Covid-19 Vaccine, Aavcovid. Available at: https://masseyeandear.org/news/press-releases/2020/05/mee-and-mghadvancing-aavcovid-vaccine.

249. Calcedo R, Vandenberghe LH, Gao G, Lin J, Wilson JM. Worldwide Epidemiology of Neutralizing Antibodies to Adeno-Associated Viruses. J Infect Dis (2009) 199(3):381-90. doi: 10.1086/595830

250. Mays LE, Wang L, Tenney R, Bell P, Nam HJ, Lin J, et al. Mapping the Structural Determinants Responsible for Enhanced T Cell Activation to the Immunogenic Adeno-Associated Virus Capsid From Isolate Rhesus $32.33 \mathrm{~J}$ Virol (2013) 87(17):9473-85. doi: 10.1128/JVI.00596-13

251. Lin J, Calcedo R, Vandenberghe LH, Bell P, Somanathan S, Wilson JM. A New Genetic Vaccine Platform Based on an Adeno-Associated Virus Isolated From a Rhesus Macaque. J Virol (2009) 83(24):12738-50. doi: 10.1128/JVI.01441-09

252. Hansen J, Baum A, Pascal KE, Russo V, Giordano S, Wloga E, et al. Studies in Humanized Mice and Convalescent Humans Yield a SARS-CoV-2 Antibody Cocktail. Science (2020) 369(6506):1010-4. doi: 10.1126/science.abd0831

253. Baum A, Fulton BO, Wloga E, Copin R, Pascal KE, Russo V, et al. Antibody Cocktail to SARS-CoV-2 Spike Protein Prevents Rapid Mutational Escape Seen With Individual Antibodies. Science (2020) 369(6506):1014-8. doi: 10.1126/science.abd0831

254. Weinreich DM, Sivapalasingam S, Norton T, Ali S, Gao H, Bhore R, et al. Regn-COV2, a Neutralizing Antibody Cocktail, in Outpatients With Covid19. N Engl J Med (2021) 384(3):238-51. doi: 10.1056/NEJMoa2035002

255. Coronavirus (COVID-19) Update: Fda Authorizes Monoclonal Antibodies for Treatment of COVID-19 (2020). Available at: https://www.fda.gov/newsevents/press-announcements/coronavirus-covid-19-update-fda-authorizesmonoclonal-antibodies-treatment-covid-19.

256. Penn Medicine Collaborates With Regeneron to Investigate Delivery of COVID-19 Antibody Cocktail Via Gene Therapy Platform (2020). Available at: https://www.pennmedicine.org/news/news-releases/2020/november/ penn-medicine-collaborates-with-regeneron-to-investigate-delivery-ofcovid-antibody.

257. Aguzzi A, Sigurdson C, Heikenwaelder M. Molecular Mechanisms of Prion Pathogenesis. Annu Rev Pathol (2008) 3:11-40. doi: 10.1146/ annurev.pathmechdis.3.121806.154326

258. White AR, Enever P, Tayebi M, Mushens R, Linehan J, Brandner S, et al. Monoclonal Antibodies Inhibit Prion Replication and Delay the Development of Prion Disease. Nature (2003) 422(6927):80-3. doi: 10.1038/nature01457

259. Sigurdsson EM, Sy MS, Li R, Scholtzova H, Kascsak RJ, Kascsak R, et al. AntiPrion Antibodies for Prophylaxis Following Prion Exposure in Mice. Neurosci Lett (2003) 336(3):185-7. doi: 10.1016/S0304-3940(02)01192-8

260. Spilman P, Lessard P, Sattavat M, Bush C, Tousseyn T, Huang EJ, et al. A Gamma-Secretase Inhibitor and Quinacrine Reduce Prions and Prevent Dendritic Degeneration in Murine Brains. Proc Natl Acad Sci USA (2008) 105(30):10595-600. doi: 10.1073/pnas.0803671105

261. Ahn M, Ghaemmaghami S, Huang Y, Phuan PW, May BC, Giles K, et al. Pharmacokinetics of Quinacrine Efflux From Mouse Brain Via the Pglycoprotein Efflux Transporter. PloS One (2012) 7(7):e39112. doi: 10.1371/journal.pone.0039112

262. Solforosi L, Criado JR, McGavern DB, Wirz S, Sanchez-Alavez M, Sugama S, et al. Cross-Linking Cellular Prion Protein Triggers Neuronal Apoptosis In Vivo. Science (2004) 303(5663):1514-6. doi: 10.1126/science.1094273

263. Klohn PC, Farmer M, Linehan JM, O’Malley C, Fernandez de Marco M, Taylor W, et al. Prp Antibodies do Not Trigger Mouse Hippocampal Neuron Apoptosis. Science (2012) 335(6064):52. doi: 10.1126/science.1215579

264. Polymenidou M, Heppner FL, Pellicioli EC, Urich E, Miele G, Braun N, et al. Humoral Immune Response to Native Eukaryotic Prion Protein Correlates With Anti-Prion Protection. Proc Natl Acad Sci USA (2004) 101(Suppl 2): 14670-6. doi: 10.1073/pnas.0404772101

265. Hudry E, Vandenberghe LH. Therapeutic AAV Gene Transfer to the Nervous System: A Clinical Reality. Neuron (2019) 102(1):263. doi: 10.1016/j.neuron.2019.03.020

266. Campana V, Zentilin L, Mirabile I, Kranjc A, Casanova P, Giacca M, et al. Development of Antibody Fragments for Immunotherapy of Prion Diseases. Biochem J (2009) 418(3):507-15. doi: 10.1042/BJ20081541

267. Emanuel J, Marzi A, Feldmann H. Filoviruses: Ecology, Molecular Biology, and Evolution. Adv Virus Res (2018) 100:189-221. doi: 10.1016/ bs.aivir.2017.12.002 
268. Henao-Restrepo AM, Camacho A, Longini IM, Watson CH, Edmunds WJ, Egger M, et al. Efficacy and Effectiveness of an rVSV-vectored Vaccine in Preventing Ebola Virus Disease: Final Results From the Guinea Ring Vaccination, Open-Label, Cluster-Randomised Trial (Ebola Ca Suffit!) Lancet (2017) 389(10068):505-18. doi: 10.1016/S0140-6736(16)32621-6

269. Rghei AD, van Lieshout LP, Santry LA, Guilleman MM, Thomas SP, Susta L, et al. Aav Vectored Immunoprophylaxis for Filovirus Infections. Trop Med Infect Dis (2020) 5(4). doi: 10.3390/tropicalmed5040169

270. Qiu X, Fernando L, Melito PL, Audet J, Feldmann H, Kobinger G, et al. Ebola GP-specific Monoclonal Antibodies Protect Mice and Guinea Pigs From Lethal Ebola Virus Infection. PloS Negl Trop Dis (2012) 6(3):e1575. doi: 10.1371/journal.pntd.0001575

271. Qiu X, Audet J, Wong G, Pillet S, Bello A, Cabral T, et al. Successful Treatment of Ebola Virus-Infected Cynomolgus Macaques With Monoclonal Antibodies. Sci Transl Med (2012) 4(138):138ra81. doi: 10.1126/scitranslmed.3003876

272. Holtsberg FW, Shulenin S, Vu H, Howell KA, Patel SJ, Gunn B, et al. PanEbolavirus and Pan-filovirus Mouse Monoclonal Antibodies: Protection Against Ebola and Sudan Viruses. J Virol (2016) 90(1):266-78. doi: 10.1128/JVI.02171-15

273. Corti D, Misasi J, Mulangu S, Stanley DA, Kanekiyo M, Wollen S, et al. Protective Monotherapy Against Lethal Ebola Virus Infection by a Potently Neutralizing Antibody. Science (2016) 351(6279):1339-42. doi: 10.1126/science.aad5224

274. Sullivan N, Yang ZY, Nabel GJ. Ebola Virus Pathogenesis: Implications for Vaccines and Therapies. J Virol (2003) 77(18):9733-7. doi: 10.1128/ JVI.77.18.9733-9737.2003

275. Jernigan DB, Raghunathan PL, Bell BP, Brechner R, Bresnitz EA, Butler JC, et al. Investigation of Bioterrorism-Related Anthrax, United States, 2001: Epidemiologic Findings. Emerg Infect Dis (2002) 8(10):1019-28. doi: 10.3201/eid0810.020329

276. Coultas JA, Smyth R, Openshaw PJ. Respiratory Syncytial Virus (RSV): A Scourge From Infancy to Old Age. Thorax (2019) 74(10):986-93. doi: 10.1136/thoraxjnl-2018-212212

277. Moayeri M, Leppla SH. The Roles of Anthrax Toxin in Pathogenesis. Curr Opin Microbiol (2004) 7(1):19-24. doi: 10.1016/j.mib.2003.12.001

278. Crompton PD, Pierce SK, Miller LH. Advances and Challenges in Malaria Vaccine Development. J Clin Invest (2010) 120(12):4168-78. doi: 10.1172/ JCI44423

279. Moorthy VS, Newman RD, Okwo-Bele JM. Malaria Vaccine Technology Roadmap. Lancet (2013) 382(9906):1700-1. doi: 10.1016/S0140-6736(13) 62238-2

280. White MT, Bejon P, Olotu A, Griffin JT, Riley EM, Kester KE, et al. The Relationship Between RTS,S Vaccine-Induced Antibodies, CD4(+) T Cell Responses and Protection Against Plasmodium Falciparum Infection. PloS One (2013) 8(4):e61395. doi: 10.1371/journal.pone.0061395

281. Kappe SH, Vaughan AM, Boddey JA, Cowman AF. That was Then But This is Now: Malaria Research in the Time of an Eradication Agenda. Science (2010) 328(5980):862-6. doi: 10.1126/science.1184785

282. Good MF, Yanow SK. A Whole Parasite Transmission-Blocking Vaccine for Malaria: An Ignored Strategy. Emerg Top Life Sci (2017) 1(6):547-52. doi: 10.1042/ETLS20170117
283. Brod F, Miura K, Taylor I, Li Y, Marini A, Salman AM, et al. Combination of RTS,S and Pfs25-IMX313 Induces a Functional Antibody Response Against Malaria Infection and Transmission in Mice. Front Immunol (2018) 9:2780. doi: 10.3389/fimmu.2018.02780

284. Echeverria N, Moratorio G, Cristina J, Moreno P. Hepatitis C Virus Genetic Variability and Evolution. World J Hepatol (2015) 7(6):831-45. doi: 10.4254/ wjh.v7.i6.831

285. Gouklani H, Bull RA, Beyer C, Coulibaly F, Gowans EJ, Drummer HE, et al. Hepatitis C Virus Nonstructural Protein 5B is Involved in Virus Morphogenesis. J Virol (2012) 86(9):5080-8. doi: 10.1128/JVI.07089-11

286. Fooks AR, Cliquet F, Finke S, Freuling C, Hemachudha T, Mani RS, et al. Rabies. Nat Rev Dis Primers (2017) 3:17091. doi: 10.1038/nrdp.2017.91

287. Rupprecht CE, Nagarajan T, Ertl H. Current Status and Development of Vaccines and Other Biologics for Human Rabies Prevention. Expert Rev Vaccines (2016) 15(6):731-49. doi: 10.1586/14760584.2016.1140040

288. Hampson K, Coudeville L, Lembo T, Sambo M, Kieffer A, Attlan M, et al. Estimating the Global Burden of Endemic Canine Rabies. PloS Negl Trop Dis (2015) 9(4):e0003709. doi: 10.1371/journal.pntd.0003709

289. Luvero D, Lopez S, Bogani G, Raspagliesi F, Angioli R. From the Infection to the Immunotherapy in Cervical Cancer: Can We Stop the Natural Course of the Disease? Vaccines (Basel) (2020) 8(4). doi: 10.3390/vaccines 8040597

290. Crosbie EJ, Einstein MH, Franceschi S, Kitchener HC. Human Papillomavirus and Cervical Cancer. Lancet (2013) 382(9895):889-99. doi: 10.1016/S0140-6736(13)60022-7

291. Ghittoni R, Accardi R, Hasan U, Gheit T, Sylla B, Tommasino M. The Biological Properties of E6 and E7 Oncoproteins From Human Papillomaviruses. Virus Genes (2010) 40(1):1-13. doi: 10.1007/s11262-009-0412-8

292. Tommasino M, Accardi R, Caldeira S, Dong W, Malanchi I, Smet A, et al. The Role of TP53 in Cervical Carcinogenesis. Hum Mutat (2003) 21(3):30712. doi: 10.1002/humu.10178

293. Boyer SN, Wazer DE, Band V. E7 Protein of Human Papilloma virus-16 Induces Degradation of Retinoblastoma Protein Through the UbiquitinProteasome Pathway. Cancer Res (1996) 56(20):4620-4.

Conflict of Interest: GG is a scientific co-founder of Voyager Therapeutics and Aspa Therapeutics, and holds equity in these companies. GG is an inventor on patents with potential royalties licensed to Voyager Therapeutics, Aspa Therapeutics, and other biopharmaceutical companies.

The remaining authors declare that the research was conducted in the absence of any commercial or financial relationships that could be construed as a potential conflict of interest.

Copyright (c) 2021 Zhan, Muhuri, Tai and Gao. This is an open-access article distributed under the terms of the Creative Commons Attribution License (CC BY). The use, distribution or reproduction in other forums is permitted, provided the original author(s) and the copyright owner(s) are credited and that the original publication in this journal is cited, in accordance with accepted academic practice. No use, distribution or reproduction is permitted which does not comply with these terms. 